IFN Working Paper No. 774, 2008

\title{
Sweden: A Minimum Wage Model in Need of Modification?
}

Per Skedinger 


\title{
Sweden: A minimum wage model in need of modification?*
}

\author{
Per Skedinger ${ }^{\#}$
}

October 23, 2008

\begin{abstract}
Swedish minimum wages are not regulated by law, but subject to bargaining between employers and trade unions and form part of collective agreements. This paper provides an overview of the Swedish minimum wage system, its characteristics and effects on employment and wages, and also discusses the challenges to the model represented by increasing low-wage competition from new EU member states and the verdict in the Laval case, related to this process and the first of its kind in postenlargement EU.
\end{abstract}

Keywords: Minimum wages, Low-wage competition, Laval case

JEL classification: J31, J52, J61, J81

\footnotetext{
* Acknowledgements: I would like to thank Petri Böckerman, John Ekberg, Björn Gustafsson, Torbjörn Hagelin and Kjell Jansson for useful discussions and for providing data. The usual disclaimer applies. This paper was prepared for the project "The Minimum Wage Revisited in the Enlarged EU: Issues and Challenges”, organised by the ILO and the EU Commission, and will be part of a forthcoming collective volume, edited by D. Vaughan-Whitehead. I gratefully acknowledge financial support from the Jan Wallander and Tom Hedelius Foundation.

\# Research Institute of Industrial Economics (IFN), PO Box 55665, SE-102 15 Stockholm, Sweden. Phone: +46 866545 53, fax: + 46866545 99, e-mail: per.skedinger@ifn.se.
} 


\section{Introduction}

Minimum wages in Sweden are not regulated by law, but subject to bargaining between employers and trade unions and form part of collective agreements. Swedish minimum wages are relatively high by international standards and have been increasing concurrently with overall real wage growth in the economy since 1995. Minimum wages are binding mainly in service sectors, such as hotels and restaurants and retail. In those sectors, minimum wages have also increased in relation to average wages.

The 'working poor' phenomenon is not pervasive in the Swedish labour market. Most of those with the lowest incomes are out of work and lack income from pensions, unemployment insurance or health insurance. These low-income earners are also highly dependent on social assistance, which for some households with children may be higher than the minimum wage in a service sector job.

Section 1 of this chapter presents information on minimum wage levels in Sweden and their relation to wages in general and minimum wages in other countries.

Section 2 discusses the effects of minimum wages on low pay and employment. Minimum wages have served to push up the lowest wages in hotels and restaurants and retail, and in the former also seem to have generated negative employment effects. In other sectors of the labour market, the impact of minimum wages on the wage structure and employment is likely to be small.

In Section 3, the sustainability of the Swedish model, with no government involvement in minimum wage setting, is discussed against the background of increasing competition from low-wage countries. The accession to the European Union of new member states from Central and Eastern Europe seems to pose specific challenges to systems with collectively agreed minimum wages in the old member states. An example of this is that firms operating temporarily with their own personnel in other EU countries should, according to the Posted Workers Directive of 1996, adhere to the minimum wage legislation of the host country. However, Sweden has no statutory minimum wages, nor are the rates in collective agreements legally extended to uncovered sectors. Since the accession of the new member states in 2004 the number of posted workers seems to have increased considerably, in particular from Poland and the Baltic countries, but the available statistics are incomplete.

The issue of posted workers has been highlighted by the labour dispute in the European Court of Justice between the Latvian company Laval un Partneri and Swedish trade unions that put the company under blockade, and subsequently out of business. On 18 December 2007, the court announced its judgment in the Laval case or the Vaxholm case, as it is also known in Sweden - which has gained considerable attention as the first of its kind in the post-enlargement EU. The court ruled against the Swedish construction workers trade union, a decision based on the absence of clearly defined minimum wages in the host country and the fact that union action was taken against a firm with a collective agreement in the country of origin.

It remains to be seen what the full implications of the Laval case will be for minimum wage setting in Sweden, but it is likely that modifications of some sort will be made. Up to now, the impact on the Swedish labour market of the inflow of posted workers seems to have been limited (as the regional analysis of wages in construction shows), but this may change if the inflow continues to increase and spreads to other sectors previously shielded from international competition, such as services.

\section{Fixing mechanisms and coverage}

In collective agreements, contractual wage increases, as well as minimum wage levels, are negotiated for various worker categories. In 2007, around 280 collective agreements were signed, most of which contained clauses regarding (differentiated) minimum wages (National Mediation Office 2008). In 2006, 35 agreements were concluded (National Mediation Office 2007). Some agreements for non-manual 
workers, especially professionals, do not contain minimum rates, as much of the wage formation is decentralised to the local level.

The agreement period is typically more than one year, 2-3 years is the usual length. This means that annual increases in minimum wages are negotiated for some years in advance, which helps employers adjust to future minimum wage levels. Within each agreement minimum wages are, or have been, laid down in accordance with the number of workers and workplace characteristics, such as occupation, age, work experience, type of employment contract and location. Agreements apply to all firms that are members of a signatory employer association in the industry, whether the workers are unionised or not. Approximately 90 per cent of all workers are covered by collective agreements. In general, minimum wages are specific to the negotiating area and nationwide.

On top of the contractual wage increases, there is also wage drift, that is, locally negotiated wage increases. Like the contractual wage increases, minimum wages are typically not subject to local bargaining. ${ }^{1}$ The minimum rates are defined as SEK per hour or month for various categories of workers, depending on negotiating area.

The minimum wages, although differentiated to a large extent, effectively function as wage floors on the labour market. During the 1990s, the tariff wage system in the nationwide agreements was largely abandoned in favour of local and more individualised wage formation. At present, less than 10 per cent of all employees are covered by tariff wages (Lindström 2008).

Minimum wages in all Nordic countries are set in collective agreements (see Table 1). Differentiation of rates is widely used in all countries. Finland - and to a much lesser extent Norway - extends the rates in the agreements to uncovered sectors. In Finland, extension is possible if the collective agreement is 'representative', which is assessed by a specific institution, the Board for Ratification of the Validity of Collective Agreements, and by the Labour Court. They have considered a contract to be representative when at least half of the workers in the industry are union members and most industries have a representative contract (Böckerman and Uusitalo 2007). In Norway, extensions have been few, however, and used mainly in the construction sector. Denmark is the country that resembles Sweden the most as it relies solely on collective agreements for the determination of minimum wages.

Since the collective agreements in the Nordic countries tend to also cover most workers with atypical employment, like fixed-term and part-time jobs as well as employment in temporary work agencies, few workers are excluded from the minimum rates. However, like in most other countries, self-employed workers are not covered.

Due to the complexity of the minimum wage systems in the Nordic countries and the absence of legislation, very little systematic information is readily available on the rates and their evolution over time. ${ }^{2}$ Consequently, there is virtually no information at all regarding the overall percentage of workers on the minimum wages, wage mobility of minimum wage workers and other important characteristics of the minimum wage systems, although the share of low-paid workers in general seems to be relatively low in all Nordic countries.

\footnotetext{
${ }^{1}$ An exception is the agreements for certain occupations among local government employees, where minimum wages may differ by municipality.

${ }^{2}$ In Sweden, the National Mediation Office started publishing information about the latest negotiated minimum wages in their annual report for 2005 (National Mediation Office 2006). To the best of my knowledge, there is nothing similar in the other Nordic countries.
} 
Table 1: Regulation of minimum wages in the Nordic countries

\begin{tabular}{|c|c|c|c|c|}
\hline & Denmark & Finland & Norway & Sweden \\
\hline Fixing mechanism & $\begin{array}{l}\text { Collective } \\
\text { agreements }\end{array}$ & $\begin{array}{l}\text { Collective } \\
\text { agreements }\end{array}$ & $\begin{array}{l}\text { Collective } \\
\text { agreements }\end{array}$ & $\begin{array}{l}\text { Collective } \\
\text { agreements }\end{array}$ \\
\hline \multicolumn{5}{|l|}{ Differentiation by: } \\
\hline industry & Yes & Yes & Yes & Yes \\
\hline experience & Yes & Yes & Yes & Yes \\
\hline occupation & Yes & Yes & Yes & Yes \\
\hline region & No & Yes & No & No \\
\hline $\begin{array}{l}\text { Legal extension to } \\
\text { uncovered sectors }\end{array}$ & No & Yes & $\begin{array}{l}\text { Yes } \\
\text { (but little } \\
\text { used) }\end{array}$ & No \\
\hline $\begin{array}{l}\text { Coverage of collective } \\
\text { agreements }\end{array}$ & $70 \%$ & $80 \%$ & $75 \%$ & $90 \%$ \\
\hline
\end{tabular}

Note: Information on differentiation is based on collective agreements for three sectors in 2006: Construction, hotels and restaurants and retail. Coverage of collective agreements refers to private sector only (except for Finland).

Source: Collective agreements, Fahlbeck (2006).

The high coverage of collective agreements in the Nordic labour markets, ranging between 70 and 90 per cent, is probably an important explanation for why minimum rates have been determined in negotiations between unions and employers and not through a legislated national minimum wage. Even more relevant would perhaps be the coverage rates in low-wage industries. EIRO (2005) reports rates between 55 and 100 per cent in retail and hotels/restaurants for Finland, Norway and Sweden. Since most workers are covered by the minimum rates, also in low-wage industries, legislation has not been regarded as necessary.

Negotiated minimum wages are not unique to the Nordic countries, however. In some countries with statutory rates, like France, Netherlands and Spain, minimum wages are also negotiated in collective agreements. What sets the Nordic countries, and especially Sweden, apart is instead the fact that the legal possibilities for unions to enforce and impose collective agreements are relatively far-reaching. The blockade undertaken by Swedish unions against the Laval company is a case in point (to which we will return in Section 4.1). Legislation regarding sympathetic actions, of unions not directly involved in a conflict, seems to be less restrictive in the Nordic countries than elsewhere and requirements of 'proportionality' of union actions are especially lenient in Sweden (Fahlbeck 2006). In addition, the high unionisation rates in the Nordic countries seem to be largely explained by the Ghent system, which is used in Denmark, Finland and Sweden and ties eligibility for unemployment insurance benefits to union membership (see Böckerman and Uusitalo 2006, for an analysis in the Finnish context).

\section{Minimum wage developments}

Due to the large number of collective agreements, the description in this section focuses on seven agreements for manual workers, namely the 'Engineering Agreement' (Teknikavtalet Metall, formerly Verkstadsavtalet), the 'Construction Agreement' 
(Byggnadsavtalet), the 'Slaughterhouse Agreement' (Slakteri- och charkuteriavtalet), the 'Bakery Agreement' (Bageriavtalet), the 'Retail Trade Agreement' (Detaljhandelsavtalet), the 'Hotels and Restaurants Agreement' (Hotell- och restaurangavtalet) and the 'Local Government Agreement' (Kommunalavtalet). The selected agreements include negotiating areas for both manufacturing and service industries, both private and public sectors, as well as some of the largest agreements on the Swedish labour market. The six unions that are signatories of the seven agreements had 1,227,000 members in 2002 (Kjellberg 2003), which amounts to 74 per cent of the total membership of the Swedish Confederation of Trade Unions (Landsorganisationen, LO). ${ }^{3}$

The basic period of study is 1995-2007. The presentation is based on a 'standardised worker' in order to achieve comparability of minimum rates across agreements and years. The characteristics of the standardised worker are as follows: at least 20 years of age, with no work experience and working in an unskilled occupation in a non-metropolitan area. A worker with these characteristics is expected to have the lowest minimum wage for an adult worker in each agreement.

The evolution of minimum rates for the standardised worker is described in nominal and real terms, as well as in relation to average wages (a measure known as the 'minimum wage bite' or the 'Kaitz index'). In addition, the degree of differentiation of minimum wages (in relation to the standardised worker) is shown, with respect to age.

\subsection{Minimum wages and the minimum wage bite}

Figure 1 shows the nominal minimum wage per hour for the standardised worker in the selected agreements during 1995-2009. Since the agreements typically specify minimum wages for a two- or three-year period, it is possible to include future levels. In general, minimum wage levels are lower in services than in other sectors. In 2007, minimum wages ranged from SEK 102.48 (€11.08) in the bakery sector to SEK 79.77 (€8.62) in local government. The Local Government Agreement specifies only monthly minimum wages (SEK 13,800 in 2007) and these have been recalculated to hourly rates. $^{4}$

Minimum wages have increased at fairly stable rates, with some exceptions in the latest agreements: bakery and slaughterhouse (unusually high percentage increases in 2007) and local government (unusually high in 2009). In the two former agreements, this is explained by a change in the structure of the agreements; up to and including 2006, minimum wages were differentiated by type of contract (permanent or fixedterm). This differentiation entailed a lower minimum for permanent employees during the first year of employment. In the latest local government agreement, minimum wages have not been adjusted in the first two years but have instead increased more substantially in the third year.

\footnotetext{
3 The Food Workers' Union (Livsmedelsarbetareförbundet) is signatory to both the Slaughterhouse Agreement and the Bakery Agreement.

${ }^{4}$ Many workers who are affected by the Local Government Agreement work fewer than 40 hours per week and also have additional holidays (Swedish Association of Local Authorities and Regions 2005). Hence the recalculation to an hourly wage is likely to understate the minimum wage in this agreement as compared to the other agreements in this chapter.
} 
Figure 1a: Nominal minimum wages, 1995-2009 (SEK per hour)

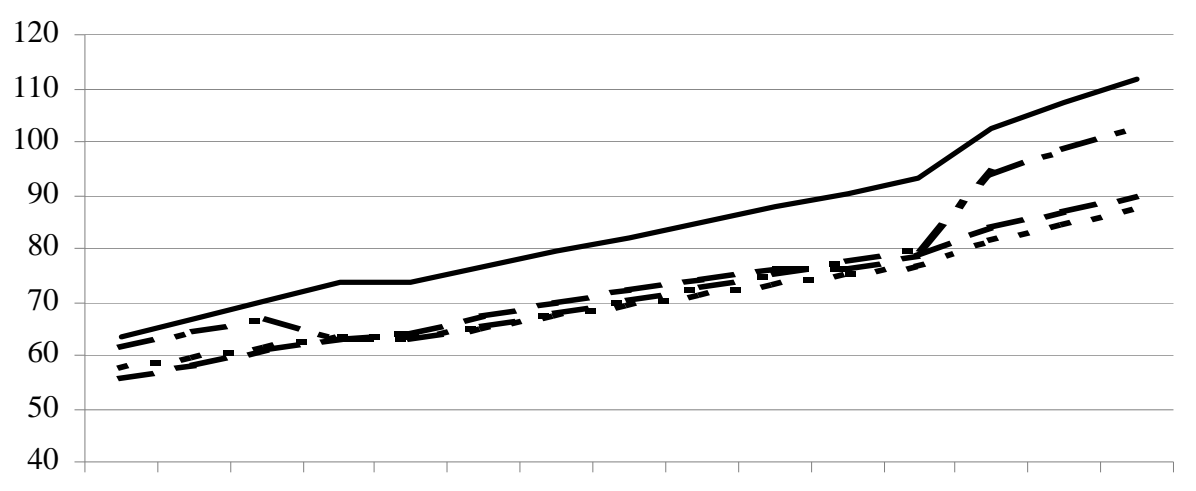

199519961997199819992000200120022003200420052006200720082009

- - - Engineering — Bakery - - Slaughter-house - C Construction Source: Collective agreements.

Figure 1b: Nominal minimum wages, 1995-2009 (SEK per hour)

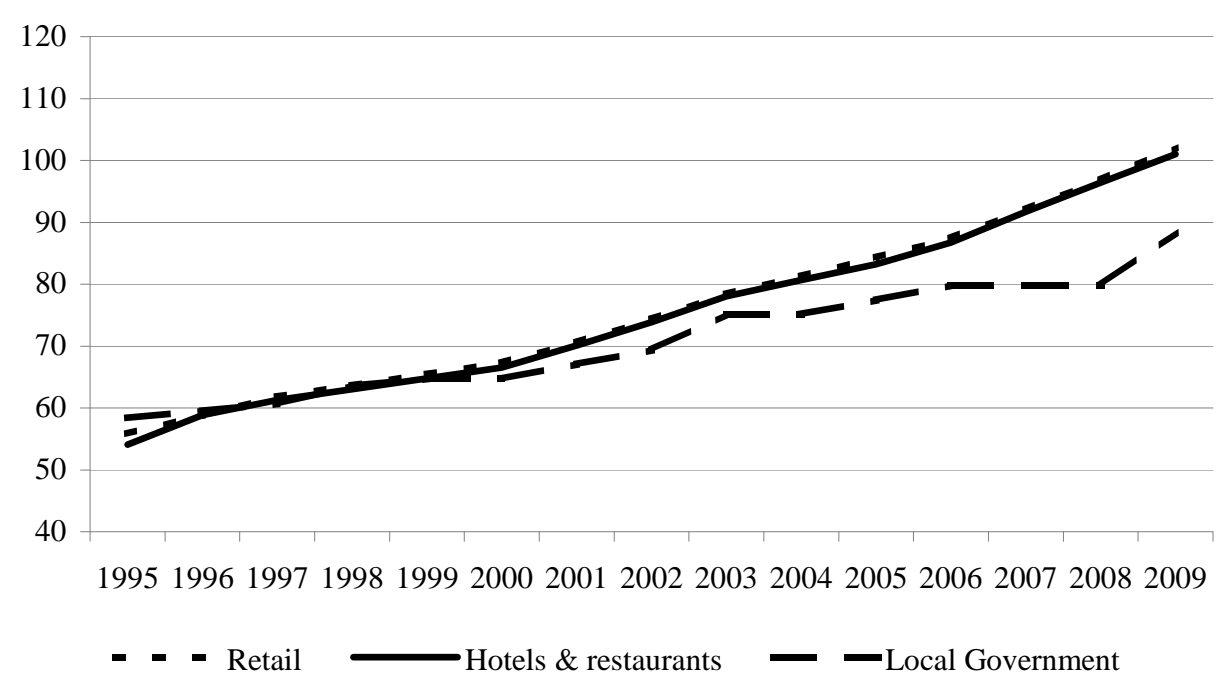

Source: See Figure 1.a.

Real minimum wages, in 2007 prices, are displayed in Figure 2. The minimum rates are deflated with the consumer price index and reflect the purchasing power before

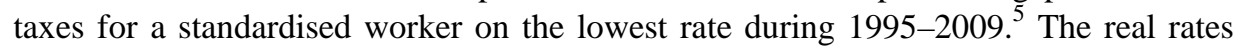
have increased considerably in all agreements from 1995 to 2007 and are likely to continue to rise in 2008-9, despite an increase in the expected inflation rate. In hotels

${ }^{5}$ Prices for 2008-9 are based on forecasts by the National Institute for Economic Research. 
and restaurants and retail, real minimum wages increased by 49 and 44 per cent, respectively, between 1995 and 2007. The lowest increase occurred in the local government sector, at 20 per cent. The increases in real minimum wages in the recent decade stand in sharp contrast to the period from the mid-1970s to the mid-1990s, when real rates were either stable or decreased somewhat (Skedinger 2005).

Figure 2a: Real minimum wages, 1995-2009 (SEK per hour)

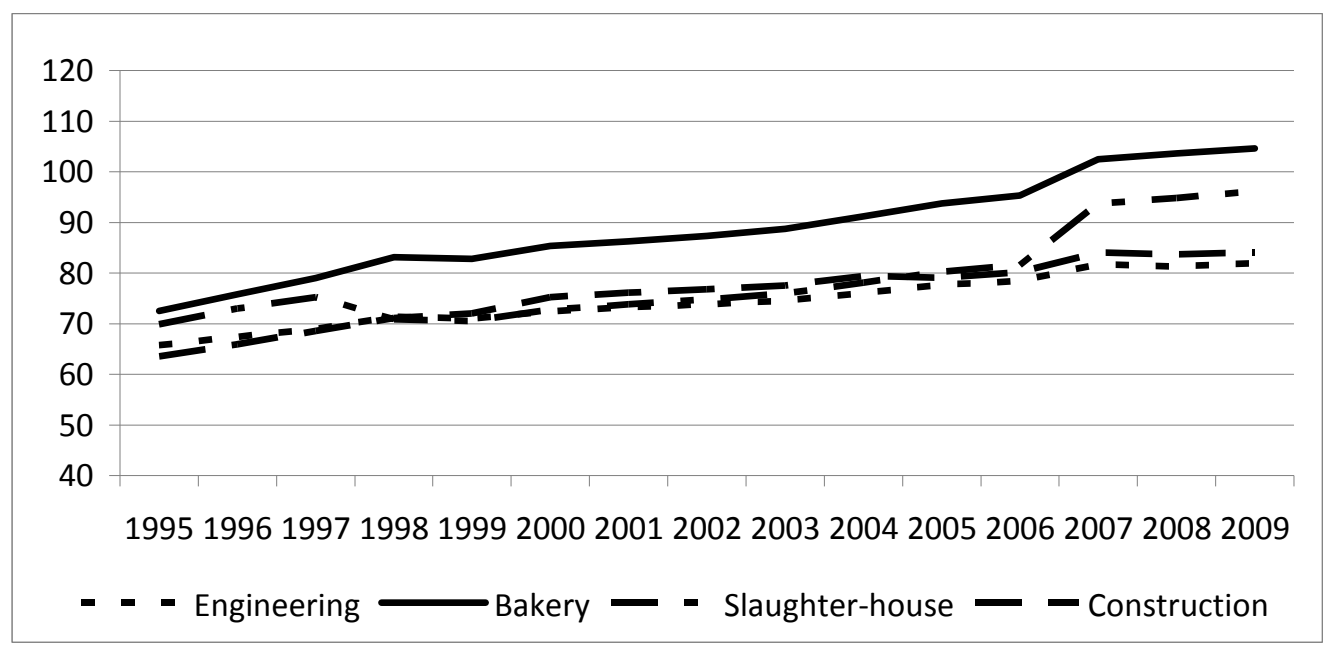

Note: 2007 prices.

Source: Collective agreements (minimum wages), Statistics Sweden (prices) and National Institute for Economic Research (price forecasts for 2008-09).

Figure 2b: Real minimum wages, 1995-2009 (SEK per hour)

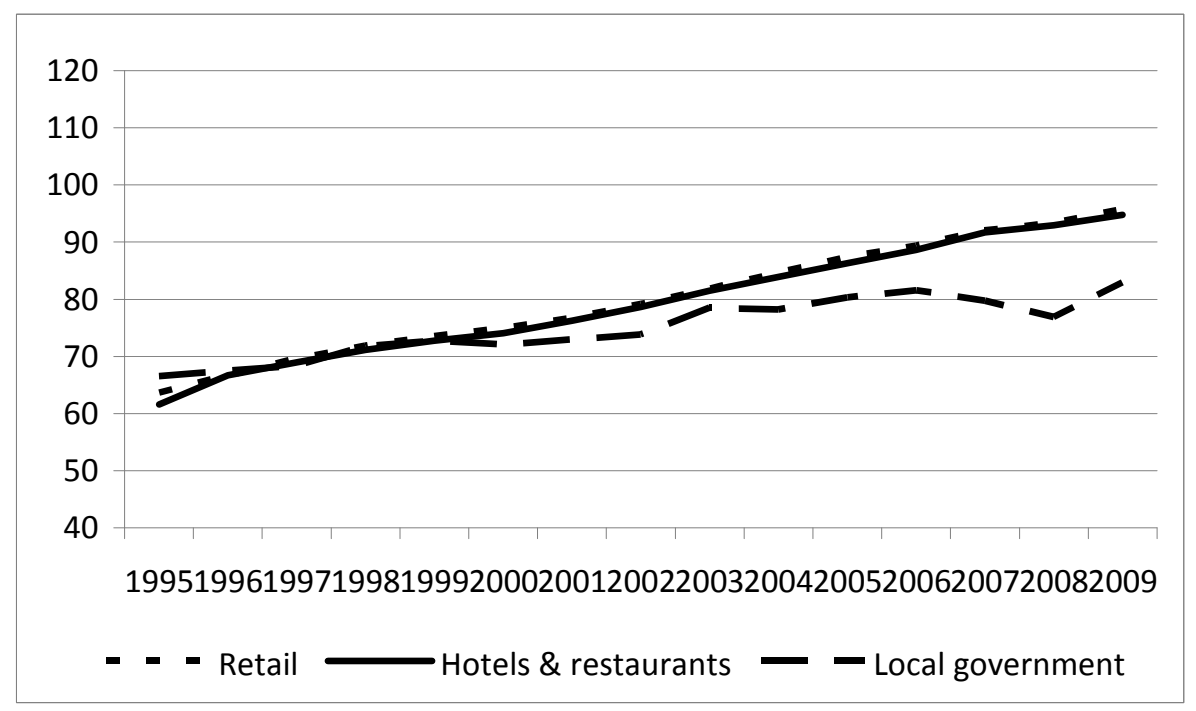

Notes and sources: See Figure 2.a. 
In the selected agreements, the criteria used for differentiation of minimum wages for adult workers included occupation, experience, age, type of contract and location over the period 1995-2006 (Skedinger 2005). The most common criterion is experience, which is used in all seven agreements at present, and occupation, which is used in all agreements except that of retail. Experience is defined in somewhat different ways in the agreements: sector- or occupation-specific experience or tenure on the present job.

Differentiation by occupation tends to be based on grouping of occupations, according to required responsibility and skill levels. A typical example is the Engineering Agreement, where four occupational groups have been used since 1983. Group 1 includes 'jobs that require insignificant or little effort in a fairly good work environment and are performed according to detailed instructions and routines'. Group 4 includes 'skilled jobs with great demands on judgement, responsibility'.

As far as the use of differentiation by age is concerned, the picture is mixed. This type of differentiation has not been used at all in some agreements, and has been used throughout the period in others. To the extent that differentiation has been used, it has been limited mainly to two groups - workers over and under 19 years of age. ${ }^{6}$ Figure 3 shows differentiation of minimum wages by age. The minimum wage for an 18 year old is contrasted to the minimum wage for the standardised worker, who is 20 years old. Construction displays the largest degree of differentiation, with a relative minimum for 18 year olds of 71 per cent since 1997. Differentiation by age in retail is relatively modest, while the hotels and restaurants sector has displayed a downward trend since 2004. In local government, agreements since 2002 do not specify minimum wages for workers below 19 years of age.

Figure 3: Differentiation of minimum wages by age, 1995-2009 (\%)

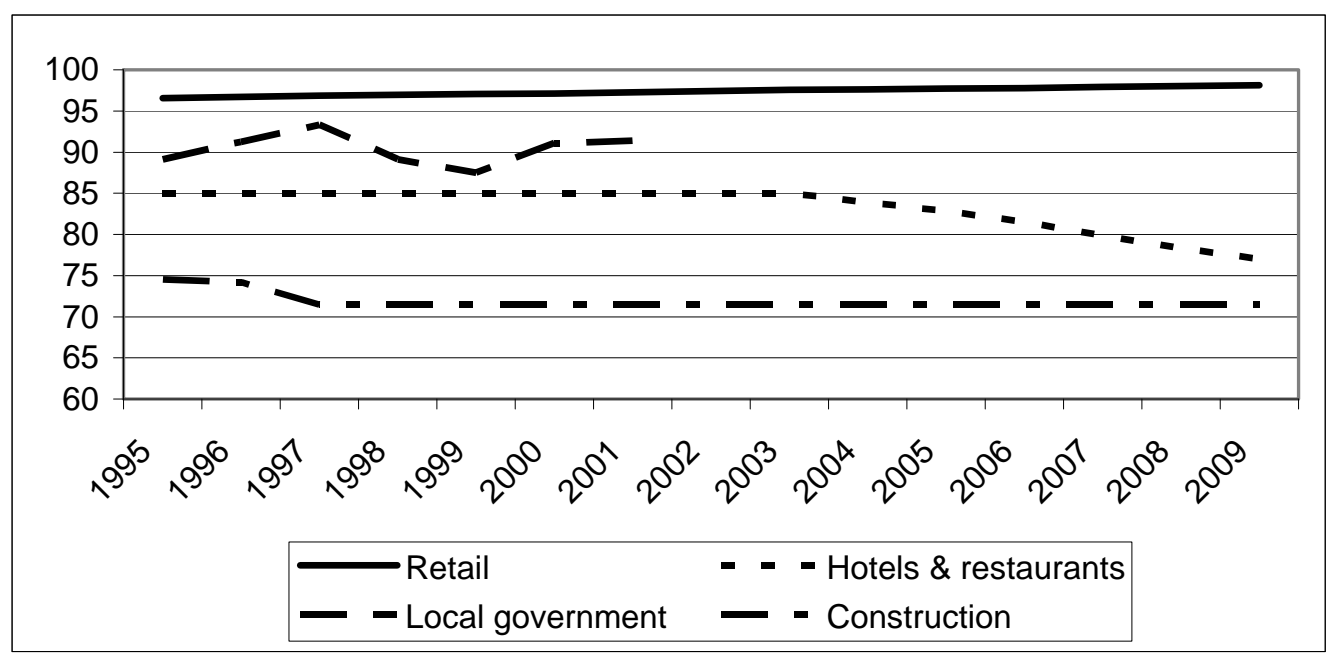

Note: Minimum wages of 18-year-olds in relation to 20-year-olds.

Source: Collective agreements.

${ }^{6}$ Differentiation by age for minors - that is, workers below the age of 18 - is not considered. Such differentiation is used in most of the selected agreements. 
A notable development occurred in the Hotels and Restaurants Agreement in 1993 (to which we will return when discussing the employment effects of minimum wages in Section 3.2). In that year, differentiation by age increased markedly as the minimum wage for 18 year olds was reduced to SEK 44.90 per hour, from SEK 51.90 the previous year, at the same time as the minimum for 20 year olds increased to SEK 52.85. This is an example of a nominal (minimum) wage reduction, which is extremely rare in collective agreements in Sweden and should be seen against the background of rapidly increasing unemployment in the first half of the 1990s.

In general, there is a trend towards more differentiation by experience and age since the 1980s, while the picture is more diverse regarding differentiation by occupation (Skedinger 2005). The first observation is well in line with the studies pointing to more wage dispersion in general since the early 1980s (Edin and Holmlund 1995). A possible explanation of the second observation, regarding differentiation by occupation, is that skill requirements have increased in certain industries, such as engineering and construction, while the distinction between different occupations has become more blurred in other sectors.

Figure 4 relates the minimum wage for the standardised worker to average wages for manual workers in the corresponding industry for the period 1995-2006. ${ }^{7}$ The highest minimum wage bite in 2006, 87 per cent, is in hotels and restaurants, while construction and engineering exhibit the lowest, at 58 and 62 per cent, respectively. It is thus to be expected that more workers are affected by minimum wages in sectors such as and hotels and restaurants than in other sectors. The role of the minimum wage is thus sector-specific to a large extent, since minimum rates are not likely to be binding in all sectors.

Figure 4a: Minimum wage bite, 1995-2006 (\%)

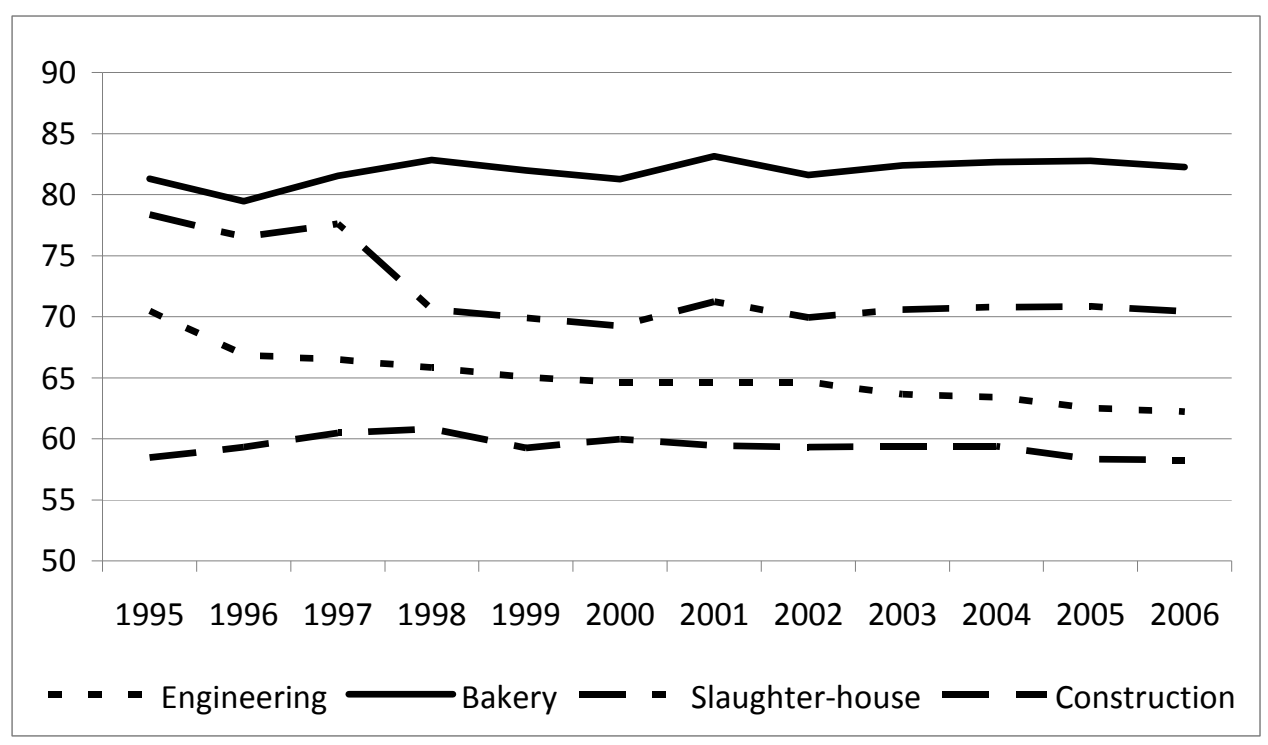

Note: Minimum wages in relation to average wages in the industry.

Source: Collective agreements (minimum wages), Statistics Sweden (average wages).

\footnotetext{
${ }^{7}$ The industries in the data on average wages do not in all cases correspond exactly to the industries in the agreements. For example, data are not available for average wages in bakeries and slaughterhouses, so data for the food industry as a whole have been used.
} 
Figure 4b: Minimum wage bite, 1995-2006 (\%)

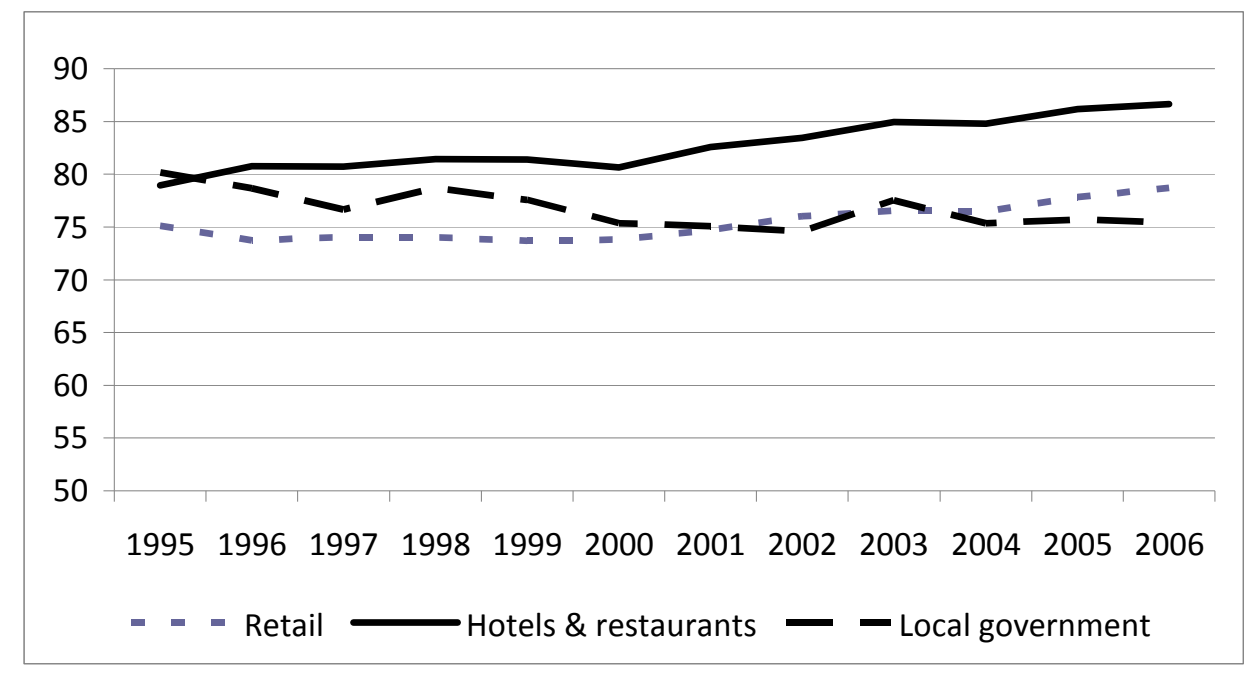

Note and source: See figure 4.a.

There is some variation across agreements in the development of the bite over time in Figure 4; in hotels and restaurants and retail there is a marked increase, especially since 2000, while the bite has decreased in slaughterhouses, engineering and local government. The increases in the bite are, however, smaller than the increases in real minimum wages (Figure 2).

The development of real wages in the whole economy is shown in Figure 5 (figures are available only for monthly wages). Average wages increased from SEK 18,200 in 1995 to 25,600 in 2006, which represents a 40 per cent increase. Median wages increased at a slightly lower rate, 36 per cent, which suggests that wage growth has been relatively stronger in the upper part of the wage distribution. It is thus clear that the minimum wage developments in the selected agreements, noted in Figure 3, are part of an overall wage growth in the economy. This development stands in sharp contrast to the period 1975-95, during which real wage growth was zero (Edin and Topel 1997). A major factor behind the wage developments since 1995 is a sustained rise in productivity over the period.

Figure 6 relates minimum wages in hotels and restaurants and retail to monthly wages in the whole economy. Monthly minimum wages for the standardised worker in hotels and restaurants are higher than in retail, despite the fact that hourly wages in the former sector are relatively lower (as seen in Figures 1-2). Over the period as a whole, the bite increased in relation to median monthly wages, while little changed relative to the average. 
Figure 5: Real wages in the whole economy, 1995-2006 (SEK per month)

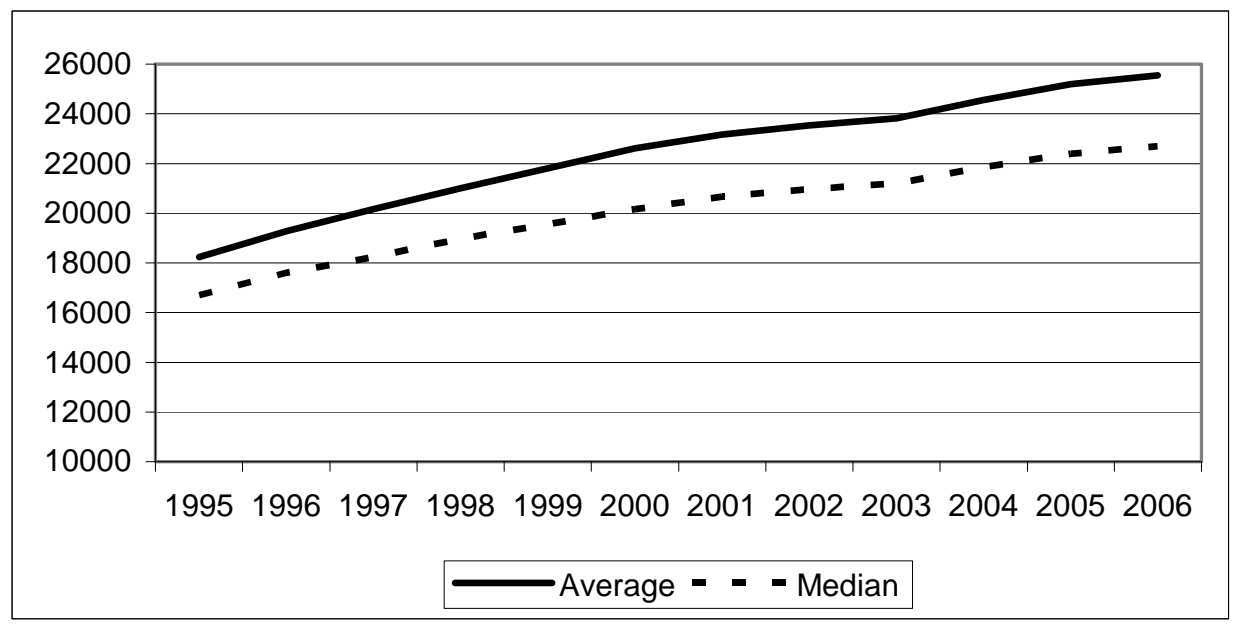

Note: 2007 prices.

Source: Statistics Sweden.

Figure 6: Minimum wages in relation to wages (average and median) in the whole economy, 1995-2006 (\%)

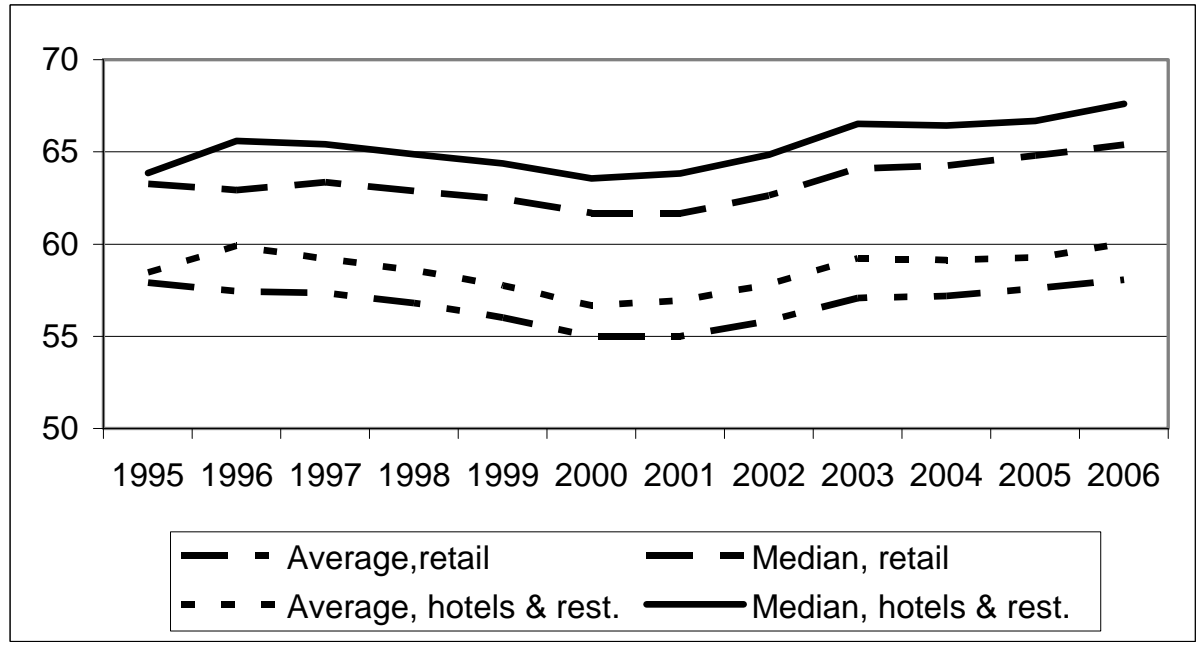

Source: Collective agreements (minimum wages), Statistics Sweden (wages).

How do Swedish minimum wages relate to those of her neighbours? Table 2 shows hourly minimum rates in the collective agreements for construction, retail and hotels and restaurants in Denmark, Finland, Norway and Sweden in 2006. ${ }^{8}$ As in previous figures, the rates pertain to 20 -year-old, unskilled workers with no previous experience

\footnotetext{
${ }^{8}$ Most agreements also specify monthly minimum wages, but these are not directly comparable across countries due to national differences in stipulated weekly working hours.
} 
(construction workers, shop assistants and restaurant assistants, respectively). The highest minimum wages levels are in Denmark and Norway and the lowest in Finland. The ranking across countries corresponds fairly well to what would be expected from the differences in the economy-wide wage levels. In relation to average wages for production workers in manufacturing, minimum wages in Denmark and Norway seem to be at about the same levels as in Sweden. The bite in Finland is, however, consistently lower than in the other Nordic countries. Whether this has something to do with the special features of the Finnish minimum wage system, such as the reliance on extension of agreements to non-covered sectors, or is explained by other factors remains an open question.

Table 2: Hourly minimum wages in the Nordic countries, 2006

$$
\text { Denmark Finland Norway Sweden }
$$

\begin{tabular}{|c|c|c|c|c|}
\hline & & & & \\
\hline $\begin{array}{l}\text { Construction } \\
\text { National }\end{array}$ & 96.15 & 7.60 & 118.00 & 78.40 \\
\hline Euros & 12.89 & 7.60 & 14.67 & 8.48 \\
\hline \multicolumn{5}{|c|}{$\%$ of average } \\
\hline manufac. & 51 & 40 & 56 & 50 \\
\hline \multicolumn{5}{|l|}{ Retail } \\
\hline \multicolumn{5}{|l|}{ National } \\
\hline Euros & 12.60 & 8.32 & 12.64 & 9.45 \\
\hline \multicolumn{5}{|c|}{$\%$ of average } \\
\hline manufac. & 50 & 44 & 48 & 56 \\
\hline \multicolumn{5}{|c|}{ Hotels and restaurants } \\
\hline $\begin{array}{l}\text { National } \\
\text { currencies }\end{array}$ & 100.24 & 8.36 & 111.98 & 86.75 \\
\hline Euros & 13.44 & 8.36 & 13.91 & 9.38 \\
\hline $\begin{array}{c}\text { \% of averag } \\
\text { wage in } \\
\text { manufac. }\end{array}$ & 53 & 44 & 53 & 55 \\
\hline
\end{tabular}

Note: Average wages for production workers.

Source: Collective agreements (minimum wages, kindly provided by Petri Böckerman for Finland), US Bureau of Labor Statistics (manufacturing wages).

The Swedish minimum wages for adult manual workers, as a percentage of median wages in manufacturing, ranged from 60 to 72 per cent in 2004, depending on agreement (Skedinger 2005). This places Sweden in the top position in relation to countries with statutory minimum wages for which comparable data have been compiled (Low Pay Commission 2005). . Judging from Table 2, the other Nordic countries are likely to also rank high in this respect.

\subsection{Incidence of low pay and poverty}

Figures from Konjunkturinstitutet, the National Institute for Economic Research (2007), reveal that in 2006 about 30 per cent of workers in hotels and restaurants were on or close to - that is, at most 1 per cent above - one of the six minimum wage levels 
defined in the agreement. The corresponding figures for retail were 20 per cent (four minimum wage levels). Only a few per cent of workers in local government and engineering turned out to be on or close to the minimum wages. The percentage of workers affected by the very lowest adult rate (for the standardised worker) is not known, but is likely to be considerably lower. No information is available for construction, bakeries and slaughterhouses, but few workers are probably on or close to the minimum wages in these agreements.

The incidence of low pay in general in Sweden is presented in Table 3. The figures are based on two different data sources, Wage Statistics (Lönestrukturstatistiken) and the Income Distribution Surveys (Inkomstfördelningsundersökningen). The former source is based on payroll records and covers all employees, while the data from the latter are limited to full-time, full-year employees, and based on register information supplemented with interviews. Wages in the former source have been recalculated to full-time equivalents. The table shows that few workers are low paid according to both sources. In the Income Distribution Surveys, about 15 per cent of employees are paid below two thirds of the average monthly wage and 6-9 per cent are paid below two thirds of the median The corresponding figures are even lower in the Wage Statistics, 7 percent and 1.5 per cent, respectively. ${ }^{9}$

The table also shows the proportion of workers who, according to the Wage Statistics, are on or slightly above (within a 1 per cent interval) the equivalent of the minimum wages in hotels and restaurants and retail, respectively. These proportions range between 0.2 and 0.4 per cent. Few workers are paid below these minimum rates, although there is an increase in both proportions over the period 2004-06. The table makes it clear that the 'working poor' phenomenon is not pervasive in the Swedish labour market. People with the lowest incomes tend to be out of work, lack income from pensions, unemployment insurance or health insurance and to be dependent on social assistance (Gustafsson et al. 2007).

Table 3: Incidence of low pay among employees, 2004-06 (\%)

\begin{tabular}{|c|c|c|c|}
\hline & 2004 & 2005 & 2006 \\
\hline \multicolumn{4}{|l|}{ Income Distribution Surveys: } \\
\hline Below 2/3 of average wage & 14.1 & 14.5 & 15.5 \\
\hline Below $2 / 3$ of median wage & 6.4 & 7.1 & 8.7 \\
\hline \multicolumn{4}{|l|}{ Wage Statistics: } \\
\hline Below 2/3 of average wage & 6.8 & 6.8 & 7.0 \\
\hline Below 2/3 of median wage & 1.3 & 1.4 & 1.6 \\
\hline On hotels and rest. minimum wage & 0.4 & 0.3 & 0.3 \\
\hline Below hotels and rest. minimum wage & 1.3 & 1.5 & 2.2 \\
\hline On retail minimum wage & 0.2 & 0.2 & 0.2 \\
\hline Below retail minimum wage & 0.8 & 0.9 & 1.3 \\
\hline
\end{tabular}

Note: All wage measures are monthly. The wage statistics are based on all employees, while the income distribution survey statistics are based on full-time, full-year employees. Being on a minimum wage is

\footnotetext{
${ }^{9}$ The large difference between the two sources is not easily explained. It is conceivable that systematic measurement errors are introduced in the Income Distribution Surveys when using self-reported working hours. Another factor contributing to the difference may be that the Surveys include sickness benefits and parents' allowances, which in general are lower than the wage. The Wage Statistics are based on the regular wage only.
} 
defined as having a wage that is at least as high as the equivalent to the minimum wage but lower than the equivalent to the minimum wage $\mathrm{x} 1.01$, regardless of occupation and industry.

Source: Wage Statistics: Own calculations based on data from Statistics Sweden and collective agreements. Income Distribution Surveys: Calculations kindly provided by Kjell Jansson, Statistics Sweden.

It is of some interest to relate the minimum wage levels in the collective agreements to an absolute measure of poverty, namely the Swedish 'poverty line'. Unlike in the United States and some other countries, there is no official measure of the poverty line in Sweden. However, the National Board of Health and Welfare (Socialstyrelsen) publishes guidelines for social assistance that specify a 'social assistance level' (biståndsnivå) for various household categories. ${ }^{10}$

Figure 7 relates real monthly social assistance levels for a single-adult household in the city of Stockholm, with and without children, to real monthly minimum wages in hotels and restaurants and retail. Social assistance levels and minimum wages are calculated net of income taxes, assuming full-time work. The social assistance beneficiary in the figure is assumed to be employed, in which case the assistance level includes work-related costs, such as union fees and costs for day care and transport to work. Minimum wages in the two sectors have increased at a faster rate than social assistance, but are still below the social assistance level for a single-parent household with two children and close to the level with one child. This could create 'poverty traps' for some households with children to the extent that it does not pay to take up a minimum wage job in relation to receiving social assistance. In order to increase labour supply incentives in general, the government introduced tax credits for earned income in 2007. The effect of the reform is seen in the figure as a notable increase in after-tax minimum wages in relation to social assistance levels.

Figure 7: Real social assistance levels (SA) and real minimum wages (MW), city of Stockholm, 1995-2007 (SEK per month, after income taxes)

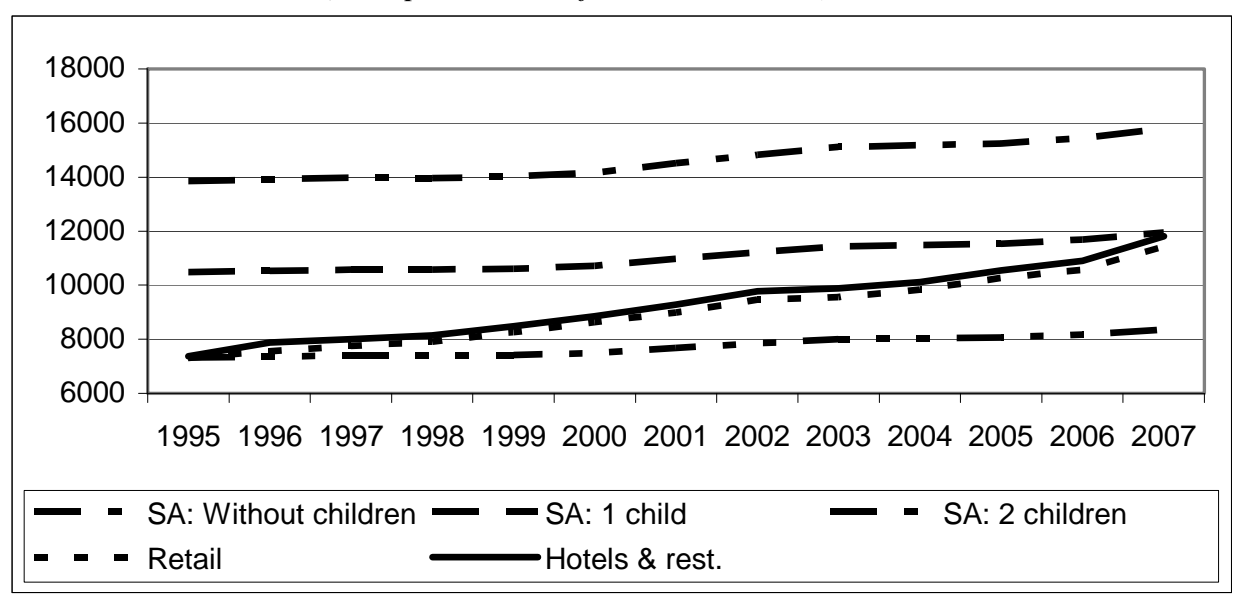

Note: 2005 prices. Social assistance refers to a single-adult household.

Source: Collective agreements (minimum wages), calculations by courtesy of Kjell Jansson, Statistics Sweden (social assistance).

\footnotetext{
${ }^{10}$ The municipalities, who are responsible for providing social assistance, are free to apply more generous standards. An individual assessment is always made of the overall economic situation of the household and incomes below the social assistance level do not guarantee financial support from the municipalities.
} 
A poverty measure sometimes used in Sweden is the number of long-term recipients (10-12 months per annum) of social assistance, aged 18 or over. According to the National Board of Health and Welfare, this number decreased from about 120,000 to around 80,000 during the period 1995-2006. Around half of these recipients are either foreign-born or have been unemployed without receiving unemployment insurance benefits during the year.

\subsection{Wage and income dispersion}

What about income and wage dispersion in general in Sweden? Figure 8 shows the Gini coefficient for disposable income during the period 1995-2005. Although the Gini is low by international standards, it increased somewhat over the period, from 0.23 to 0.27. According to Figure 9, which shows the ratio of monthly wages in the 90th to the 10th percentile, top wages rose in relation to low wages during the same period. The figure hides important differences across worker groups and sectors. Top wages have increased most rapidly among non-manual workers in the private sector (National Institute for Economic Research 2007). Among manual workers in the same sector, the P90/P10 ratio has not changed much.

Figure 8: Gini coefficient for disposable income, 1995-2005

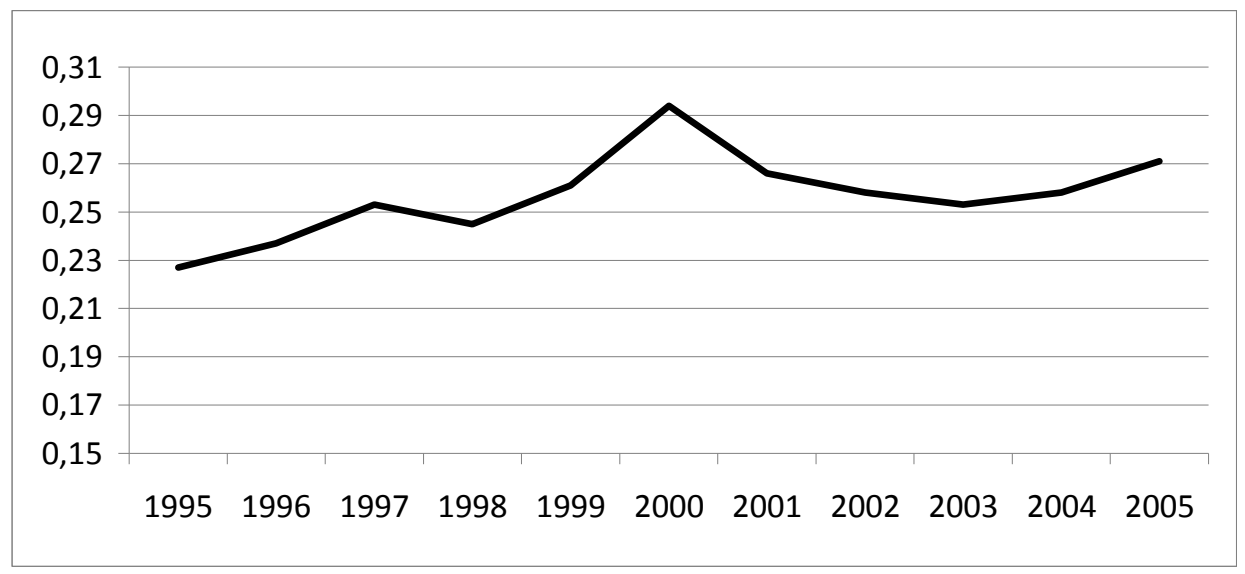

Source: Statistics Sweden, Income Distribution Surveys.

A development towards greater wage dispersion has been observed also in many other countries, especially the United States and the United Kingdom. The underlying, and interacting, factors can be divided into those that affect the demand for labour, the supply of labour and institutional factors (see, for example, Katz and Autor 1999). Globalisation in the form of increased trade with low-income countries and technological development has changed demand in favour of skilled workers. Supply factors depend mainly on the educational level of the labour force, but migration may become increasingly important in the enlarged EU. 
Figure 9: The P90/P10 ratio in the whole economy, 1995-2006

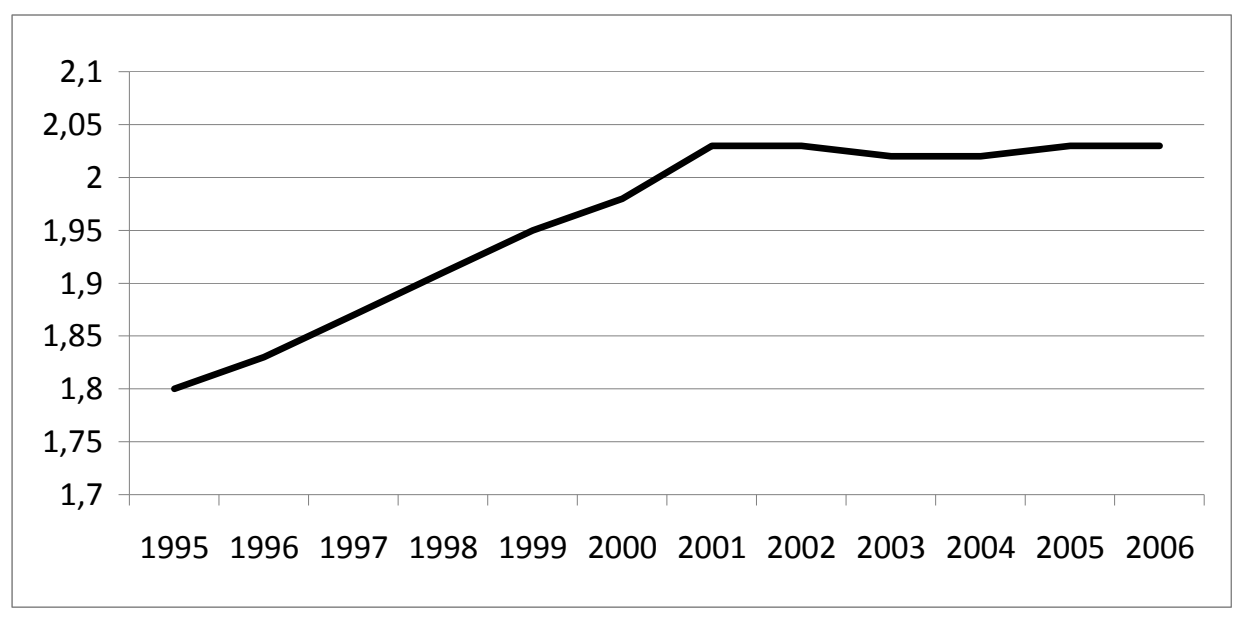

Source: Statistics Sweden, Wage Statistics.

An institutional factor of particular relevance in the Swedish context is the tendency towards less centralised wage formation since the 1980s. While membership of manual workers' unions (LO) has decreased over time, unions for non-manual workers, the Swedish Confederation for Professional Employees (Tjänstemännens Centralorganisation, TCO) and the Swedish Confederation of Professional Associations (Sveriges Akademikers Centralorganisation, SACO), have grown to approach LO in total membership. The wage policies of the two latter organisations differ from LO's, in terms of being less aimed at wage compression. For example, unlike the LO agreements, many agreements for non-manual workers do not contain any clauses regarding minimum wages. According to the National Institute for Economic Research (2007), wage dispersion in the lower half of the distribution (P50/P10) increased in all sectors except for manual workers in the private sector during 1996-2006. Furthermore, wage dispersion is greater and has increased more in highly decentralised agreements, with more local wage formation. Decentralisation has been most pronounced in agreements for central government employees and nonmanual workers, and least so for manual workers in the private sector.

Another development is that wage dispersion between establishments has increased, which may be explained by the shifts towards local wage formation in some sectors (Nordström Skans et al. 2006). Under local bargaining, firm profitability is more likely to have an influence on wage differentials.

\section{Minimum wage effects}

This section considers the effects of minimum wages on the wage structure and employment. Since minimum wages seem to be binding only in two sectors, hotels and restaurants and retail, effects are likely to be concentrated there. This section also considers studies of minimum wage effects in other Nordic countries, where available.

\subsection{Specific effects from collectively agreed minimum wages}

Very little research seems to have been carried out on the effects of collectively agreed minimum wages in general. This stands in sharp contrast to the vast research output for countries with statutory rates. In a recent survey of the 'new minimum wage research' 
since the early 1990s, only one of 102 cited works dealing with employment effects originates from a country with collectively agreed minimum wages (Neumark and Wascher 2007).

Some researchers have argued that negotiated rates, since they are applied voluntarily by employers, should be associated with only mild employment effects (see, for example, Bazen 2000). It has also been pointed out that it is possible that unions and employers have a good sense of what constitutes a relevant market wage for unskilled workers and use this information to set minimum wages that are associated with weak distortionary effects on the labour market (Neumark and Wascher 2004). Others have put forward the hypothesis that unions in European countries use increases in the minimum wage as a launch pad for their wage demands, leading to a larger wage spillover effect and a more adverse effect of the minimum wage on employment than in the United States (Dolado et al. 2000). Since workers move up the wage scale with age and tenure under collectively agreed minimum wages, spillovers may be even larger in such systems. Neumark and Wascher (2004) argue that the presence of unions in the negotiating process may result in a higher minimum wage than otherwise, which could affect employment adversely. It thus seems to be an empirical issue whether employment effects are more adverse or not with collectively agreed minimum wages.

It is not easy to assess the influence of collectively agreed minimum wages on the functioning of the labour market. Not only are such systems highly complex, as shown in this chapter, but collectively agreed rates also tend to co-exist with other institutions, such as strong reliance on active labour market policies and stringent labour standards regarding work hours and work rules, which are also likely to affect the workings of the labour market.

\subsection{Effects on wage dispersion}

Wage dispersion in the lower half of the distribution (P50/P10) decreased somewhat in the Hotels and Restaurants Agreement, from 1.18 in 1996 to 1.15 in 2006 (National Institute for Economic Research, 2007). This could be due to the increase in the minimum wage bite in this sector. Wage dispersion according to this measure has remained stable in retail and in local government.

A detailed examination of wage distributions in the various agreements in 2006 reveals that the effects of minimum wages seem to be present mainly in hotels and restaurants and retail (National Institute for Economic Research 2007). The wage distribution in the Engineering Agreement is shaped almost like a normal, singlepeaked distribution. In contrast, the wage distributions in the two service sectors display marked spikes at the different minimum wage levels. Local government is an intermediate case, with smaller spikes at the two minimum wage levels in that agreement but otherwise a shape similar to engineering. Judging from the wage distributions, minimum wage regulation seems to have pushed up the lowest wages for workers in hotels and restaurants and retail, but not to have had much effect in other agreements for which data are available.

What about spillover effects? With increasing minimum wages, say, firms may wish to substitute workers with higher marginal productivity for lower-productivity workers, thereby increasing demand and wages for the former, high-skilled group of employees. There may also be a ripple effect if high-wage workers increase their wage claims in order to restore wage differentials, when concerns about relative wages matter in wage formation. The analysis carried out by the National Institute for Economic Research (2007) suggests that increases of minimum wages in local government and hotels/restaurants have been associated with wage increases for all workers, but not as large (in percentage terms) as the minimum wage increases. .

Effects of minimum wages on wage distribution have also been analysed more formally by Edin and Holmlund (1994) and Östros (1994). Data aggregated by industry 
(for manual workers in the engineering, sawmills, paper and wood industries and for non-manual workers in mining and manufacturing) are used for the period 1971-92. The two studies examine the extent to which increasing minimum wages have contributed to the increasing relative wages for young workers that have been observed (especially during the first half of the 1970s). The results suggest that both increasing minimum wages and lower labour supply of young workers - that is, the size of the population cohorts - have contributed to increasing wages for this group. The effects of minimum wages are larger for manual than for non-manual workers; the wage elasticities, which are dependent on age group, are 0.6 and $0.05-0.2$, respectively. This means that a 10 per cent hike in the minimum wage increases wages by 6 per cent for manuals and 0.5-2 per cent for non-manuals.

All in all, the empirical evidence clearly indicates that minimum wages affect and compress the bottom part of the wage distributions in retail and hotels/restaurants. Effects on wage distributions in other sectors are probably less pronounced. Relatively little is known about spillover effects further up in the wage distributions.

\subsection{Effects on employment}

Skedinger (2006) analyses employment effects of minimum wage rates in hotels and restaurants during 1979-98. As demonstrated in Figure 2, this is the industry with the highest minimum wage bite in Sweden (86 per cent in 2006). So, if any adverse employment effects of minimum wages exist, they are likely to show up here. In the analysis, the approach in Abowd (2000a, 2000b) and Kramarz and Philippon (2001) is used and modified. This approach utilises a 'natural experiment', based on the position of individual workers in the wage distribution. Employment outcomes in a 'risk group' that is potentially affected by minimum wage changes - individuals with a wage near the minimum - are compared to outcomes for a control group. ${ }^{11}$ A distinction is made between the possibility of an increased outflow from employment due to real minimum wage increases (between two consecutive years) and the possibility of an increased inflow because of real minimum wage decreases. The two flows are not necessarily symmetric.

The results in Skedinger (2006) indicate that real minimum wage increases are associated with an increased probability of job separations, relative to the control group. To a certain extent, the probability of job accessions also increases when real minimum wages decrease. The estimated effects are relatively large; an increase of the minimum wage by 10 per cent tends to decrease the employment probability in the risk group by about 5 per cent. ${ }^{12}$ As minimum wages are more binding in hotels and restaurants than in other industries, these results may represent an upper bound of the employment effects in Sweden. Another notable result in the study is that no employment effect is found for teenagers (aged 18-19) during the period 1993-98. A possible explanation of this finding is the introduction of age-differentiated minimum rates in 1993 (as discussed in Section 2.1). This change in the design of the minimum wage system reduced the rates for teenagers in the industry considerably.

\footnotetext{
${ }^{11}$ The control group is defined as employees with the same minimum wage as the risk group and wages within an interval just above the wages of the risk group (as in Abowd 2000a, 2000b and Kramarz and Philippon 2001), and alternatively as a group within the same wage interval as the risk group, but with a lower minimum wage. The latter approach is feasible due to the differentiation of minimum wages.

${ }^{12}$ It should be noted that the implied elasticity $(-0.5)$ is conditional on previous employment and is thus not directly comparable to the unconditional elasticities that are typically estimated in the literature. However, conditional elasticities may be of specific interest since they concern the individuals who are most likely to be affected by minimum wages.
} 
Results in Edin and Holmlund (1994) also point to negative employment effects of minimum wages. The study uses data aggregated by industry and concerns 18 year old workers in manufacturing during 1972-91.

There are few studies examining employment effects of collectively agreed minimum wages in other Nordic countries and the results are mixed. Böckerman and Uusitalo (2007) examine the effects of temporary exceptions to minimum wage regulations in Finland in 1993-95 and find that they had no employment-increasing effects in the retail sector. Apparently, few employers used the opportunity to pay subminimum wages to young workers made possible by the exceptions. Askildsen et al. (2000) report small effects on transitions from employment to unemployment from increased minimum wages in Norway during the period 1991-95. For Denmark, Albæk and Strøjer Madsen (1987) find negative employment effects of minimum wage increases in the late 1970s.

A conclusion from the empirical evidence is that there is a risk of negative effects on employment of unskilled workers if the minimum wage level is set "too high". It is, however, difficult to pinpoint exactly where this level lies from existing research. While not all studies indicate negative effects, there is no study that suggests that minimum wages have positive effects on employment (in consistence with monopsony theories that emphasise the role of search frictions and mobility costs on the labour market). This does not rule out that minimum wages could have positive effects on other outcomes, like training and worker productivity, but so far there is no evidence available that could shed light on these issues.

\section{Case studies}

The public debate on minimum wage issues has been rather limited in Sweden. The likely explanation is that minimum wages are collectively agreed and thus determined outside the political system. Minimum wages are rarely on the political agenda, in contrast to many countries with statutory minimum rates. However, in the aftermath of the Laval case, this seems to be changing. The purpose of this section is to discuss the Laval case and assess its implications for wage and minimum wage formation in Sweden, in the form of two 'case studies'. The first case study deals with the reactions of the government, unions and employers in the Laval case. Our second case study considers labour migration from the new EU member states to Sweden and its consequences for wages in the construction sector.

\subsection{Case study 1: The turmoil provoked by the Laval case}

\section{The European Court of Justice decision}

On 18 December 2007 the European Court of Justice announced its judgment in the Laval case, which has gained considerable attention as the first of its kind in the postenlargement EU. The case concerned a labour dispute between the Latvian company Laval un Partneri and Swedish trade unions that put the company under blockade, and subsequently out of business. The company posted Latvian construction workers for a school building project to the town of Vaxholm in 2004.The court ruled against the Swedish Construction Workers' Union., a decision that was based on the absence of clearly defined minimum wages in the host country and the fact that union action was taken against a firm with a collective agreement in the country of origin. According to the court, wage rates must be predictable for foreign companies and it will thus not be possible to negotiate these rates for posted workers on a case-by-case basis at the firm level, as the Swedish union wished to do with Laval, in the future.

Under the Posted Workers Directive, which came into force in 1996 and applies to all EU and EES countries, firms from member countries temporarily operating in 
another member country should not pay wages below the legal minimum wage in the host country. However, Sweden neither has a legal minimum nor legally extends collectively agreed minimum rates to uncovered sectors.

\section{Possible strategies}

The immediate reaction by the Swedish government to the court's ruling was to initiate the preparation of an official report that should form the basis for a bill presented to the Riksdag in spring 2009. The commission, which should present its report no later than 15 December 2008, has been instructed to come up with suggestions on how to preserve the basic structure of the Swedish model of labour market relations without this coming into conflict with EU law.

The adjustments in the Swedish model of minimum wage setting could be relatively minor or involve a transition to statutory minimum wages or legal extension of the rates in the agreements to uncovered sectors, as has been done already in Finland and, to a lesser extent, in Norway. Sweden and Denmark do not extend collective agreements to uncovered sectors, so these countries continue to rely on collective agreements only for minimum wage setting. The Nordic countries have thus adopted somewhat different strategies so far in regulating minimum wages for posted workers.

\section{Standpoints and actions taken by unions and employer organisations}

Unions and some employer organisations in Sweden have expressed an opinion on how to deal with the Laval verdict with regard to minimum wages.

All unions, irrespective of the type of labour they organise, are critical of the verdict and have taken a position against both statutory minimum wages and legal extension to uncovered sectors. One likely explanation of this stance is that a legal minimum wage would be lower than the collectively agreed rates and would also not be differentiated by industry. Another reason may be that, although legal extension would entail higher minimum wages, incentives for union membership would be reduced. The latter argument may have gained additional importance because of the tendency towards declining union membership in recent years.

On the employers' side, the picture is more mixed. The Confederation of Swedish Enterprise (Svenskt Näringsliv), although welcoming the judgment in the Laval case, has at time of writing (September 2008) not yet taken a definitive position on its implementation. One large member organisation, the Association of Swedish Engineering Industries (Teknikföretagen), has called for national minimum wage legislation (Weihe 2008). According to their interpretation of the Swedish model, it would be an anomaly if employers and unions were to regulate conditions, such as minimum wages, for legal entities that are not members of their respective organisations. This would go against the idea of voluntary participation. Hence a legal minimum wage should be introduced for both foreign and Swedish firms. Another member organisation, the Swedish Trade Federation (Svensk Handel), does not see a need for legislated minimum wages (Jacobsson 2008). Unlike in the engineering industry, no companies enter Sweden on a temporary basis and compete with lower wages, and the minimum wage in the collective agreement is already high in relation to average wages. For these reasons, the organisation is not pushing for legislation, but would not oppose it if both employers and unions supported it.

Some actions have also been taken by unions and employer organisations in response to the Laval conflict and the verdict. A possibility of temporary membership of the Swedish Confederation of Enterprise for foreign firms was introduced in 2005, through an agreement with LO and the bargaining cartel for non-manual workers (Privattjänstemannakartellen, PTK). So far few firms have applied for temporary membership. This may be explained by the fact most firms are in the country on a short-term basis, which reduces the value of membership. Unions have also tried to 
recruit members among workers from the new EU countries. These efforts seem not to have been particularly successful either, at least as far as construction is concerned (Niklasson and Connheim 2008). The short-term nature of the association with the Swedish labour market reduces incentives also for union membership. In addition, it is conceivable that temporary workers from the new EU member states use a different comparison norm for wages than the one used by Swedish unions: the lower wage rates in the home countries rather than the higher Swedish wages.

The Swedish Construction Workers' Union has, however, gained some success in being able to sign more collective agreements with foreign firms employing posted workers (as will be discussed in more detail in the next case study). These so-called application agreements (hängavtal) can be signed by firms that are not members of an employers' organisation, but are otherwise identical to regular agreements as far as the contents are concerned (such as minimum wage rates). However, an important difference is that the possibilities are more limited for assuring that the employers follow the application agreements, since monitoring is performed by the unions and posted workers typically are not members of Swedish unions.

\section{Impacts on collective bargaining in the future}

The outcome in the Laval case has also exerted upward pressure on minimum wages in some post-verdict collective agreements and led to the introduction of such rates in agreements in which previously no minimum wages have been negotiated. An example of the latter is the latest agreement of the Swedish Association of Health Professionals (Vårdförbundet), the main union organising registered nurses. ${ }^{13}$ The verdict in the Laval case and increasing labour mobility in Europe were cited by the trade union chair, during negotiations with the employer side, as two of the motivations behind the desire to introduce a minimum wage (Eklund 2008). It remains to be seen how widespread this practice will become among other unions without minimum wages, most of which organise non-manual labour. LO has announced that it may change its wage policy, reverting to the old system with tariff wages, as a direct response to the Laval verdict (Lundby-Wedin and Olausson 2008).

Since a majority of the latest and most important agreements for manual workers were negotiated in the first half of 2007 - well before the verdict in the Laval case that apparently came as a surprise to the unions - it is too early to generalise about the impact of the court ruling on collective agreements. But the actions already taken by the Swedish Association of Health Professionals and those contemplated by LO clearly go against the development of increasing decentralisation of wage formation since the 1990s.

\subsection{Case study 2: In-migration of posted workers: A wage-depressing effect?}

A discussion of the significance of the Laval case requires information about the number of posted workers in Sweden. Unfortunately, such information is very incomplete. Migrants to Sweden mainly for labour market reasons (that is, excluding students, pensioners and close relatives of migrants with permanent residence permits) may enter the country either as individual migrants or as posted workers. The traditional type of migrant is the individual worker who seeks job opportunities in domestic firms. The posted worker is a relatively new type of migrant who works for a

\footnotetext{
${ }^{13}$ A minimum wage rate was introduced in the three-year agreement for 2008-11, which was preceded by a one-month strike. The minimum rate applies to nurses and some other worker categories with at least one year's experience, amounts to SEK 21,100 per month, is in effect from March to December 2009, and is thus not permanent (Swedish Association of Local Authorities and Regions 2008).
} 
firm temporarily operating in the country of destination. Unlike many other EU countries, Sweden did not impose restrictive transitional rules for migrants from the new member countries in 2004.

The number of posted workers in Sweden is not known. However, there is some information on the number of migrants from the new EU member states. For work spells of longer duration than three months registration with the Swedish Migration Board (Migrationsverket) is necessary for migrants in accordance with the EES agreement. Statistics for the period 2000-07 are presented in Table 4. The figures refer to registrations (permits before 2006) for work-related reasons only, that is, for 'employees', 'self-employed persons' and 'consultants'. ${ }^{14}$ Data are presented for old EU, new EU as well as non-EU countries. These categories could include a number of posted workers, but the number of unrecorded cases is probably large.

Table 4: Residence permits/registrations in accordance with the EES agreement, for labour market reasons, by country of citizenship, 2000-07

$$
2000200120022003200420052006 \quad 2007 \quad 2000-07
$$

Old EU $\quad 3223282630543254300834133632312325533$

(excl. Nordic)

of which

Germany $\quad 912 \quad 864 \quad 1060 \quad 1307 \quad 11391447 \quad 1507 \quad 12729508$

$\begin{array}{llllllllll}\text { New EU } & 0 & 0 & 0 & 2 & 3714 & 5202 & 6489 & 5761 & 21168\end{array}$

of which

\begin{tabular}{|c|c|c|c|c|c|c|c|c|c|}
\hline \multicolumn{10}{|l|}{$\begin{array}{l}\text { Bulgaria } \\
\text { Czech }\end{array}$} \\
\hline Republic & & & & 0 & 97 & 187 & 124 & 120 & 528 \\
\hline Estonia & & & & 0 & 333 & 344 & 346 & 130 & 1153 \\
\hline Hungary & & & & 0 & 164 & 240 & 348 & 320 & 1072 \\
\hline Latvia & & & & 0 & 247 & 233 & 253 & 139 & 872 \\
\hline Lithuania & & & & 0 & 587 & 796 & 744 & 451 & 2578 \\
\hline Poland & & & & 0 & 2208 & 3254 & 4508 & 3386 & 13356 \\
\hline Romania & & & & 2 & 0 & 0 & 0 & 740 & 742 \\
\hline Slovakia & & & & 0 & 61 & 120 & 105 & 114 & 400 \\
\hline Slovenia & & & & 0 & 12 & 17 & 32 & 12 & 73 \\
\hline Non-EU & 3 & 1 & 20 & 47 & 45 & 56 & 43 & 0 & 215 \\
\hline All countries & 3226 & 2827 & 3074 & 3303 & 6767 & 8671 & 10164 & 8884 & 46916 \\
\hline
\end{tabular}

Note: Labour market reasons apply to 'employees', 'self-employed persons' and 'consultants', but exclude 'students', 'close relatives' and 'pensioners'.

Source: Swedish Migration Board.

The main message of the table is that the inflow of migrants is relatively small, but there is a clear increase from the new member countries. The total number of registrations is about 47,000 over the whole period, with a strong increase in registrations from the new EU countries in 2004 and in subsequent years (and for the most recent member countries Bulgaria and Romania in 2007). Poland accounts for

\footnotetext{
${ }^{14}$ Registrations for 'students', 'close relatives' and 'pensioners' have thus been excluded. While it cannot be ruled out that some persons in these categories are also working while in Sweden, it seems less likely that a large proportion of them are posted workers.
} 
about two thirds of the registrations from the new member countries. Registrations for the old EU members, with Germany as the main country of citizenship, have remained at a fairly stable level during the period.

It should be kept in mind that the number of posted workers may well be higher than the figures for individual migrants in Table 4. If so, labour migration to Sweden would thus mainly occur through the Posted Workers' Directive rather than through individual migration. ${ }^{15}$ In addition, there is likely to be an unknown number of illegal workers residing in the country. The Swedish Construction Workers' Union estimates that there are 10,000 foreign workers in construction alone (Niklasson and Connheim 2008), out of about 290,000 employees in this sector (in 2007).

\section{A shift to self-employment?}

A potential response to high minimum wage levels in the collective agreements or an increase in the monitoring of foreign firms' wage practices by unions may be to switch from regular employment to self-employment. No wage regulations apply to the latter category of workers. However, Table 5 shows that registrations for self-employment account for less than 5 per cent of all registrations for labour market reasons, and the share is not higher among citizens from the new EU member countries than for citizens from the old EU countries. Thus, there is little evidence, so far, of a shift to more selfemployment as a response to high wage levels in Sweden.

Table 5: Residence permits/registrations in accordance with the EES agreement for self-employment, relative to permits/registrations for all labour market reasons, by country of citizenship, 2000-7 (\%)

$2000 \quad 20012002 \quad 2003 \quad 200420052006 \quad 2007 \quad 2000-7$

Old EU

(excl.

$\begin{array}{llllllllll}\text { Nordic) } & 3.4 & 2.6 & 3.7 & 4.1 & 4.7 & 5.8 & 5.0 & 5.0 & 4.3\end{array}$

$\begin{array}{lllllll}\text { New EU } & 3.6 & 6.2 & 4.2 & 4.9 & 4.8\end{array}$

$\begin{array}{llllllllll}\text { All countries } & 3.4 & 2.6 & 3.7 & 4.0 & 4.1 & 6.0 & 4.5 & 5.0 & 4.5\end{array}$

Note and source: See Table 4.

\section{Collective agreements with foreign firms}

Another way of shedding light on the migration of posted workers is to consider the number of collective agreements that Swedish unions have signed with foreign companies operating in Sweden on a temporary basis. These firms are likely to employ posted workers, mainly from the country of origin. An overwhelming majority of the agreements are application agreements, as mentioned previously, which apply to firms, regardless of nationality, that are not members of a Swedish wage-negotiating employer organisation. These agreements are basically identical to the regular agreement for member firms. A small number of agreements are also made with foreign companies with temporary membership of an employer organisation.

I have chosen to examine more closely the number of collective agreements in the construction sector, where many posted workers are active. The data cover agreements

\footnotetext{
${ }^{15}$ Dølvik and Eldring (2008) argue that the inflow of posted workers is greater than the inflow of individual labour migrants in all Nordic countries.
} 
with the Swedish Construction Workers' Union during 2000-07. Most of the foreign companies in this industry are small and act as sub-contractors in large construction projects. The firms in the data typically operate in Sweden for about a year, but there is a great deal of variation. ${ }^{16}$ A drawback with the data is that they refer to the number of agreements and do not contain information on the number of workers involved. However, unlike other sources, data are available on the regional distribution of activities. $^{17}$

\section{Significant arrival of firms from new EU member states}

Table 6 shows the number of collective agreements in the construction industry, by enterprise country of origin. The main conclusion from the table is that the number of firms from new EU countries has increased since 2004, but that this also holds for an old EU country such as Germany, as well as for Sweden. While the overall increase in agreements reflects the boom in the construction sector over the period, it is also seems to be more competition from low-wage countries in the construction industry than before. The new member country with most agreements is Poland, with about half of all agreements for firms from these countries. The agreements with foreign companies are still few in relation to those for firms permanently operating in Sweden (about 6 per cent of the total in 2007).

\section{Distance is important for location choices}

The regional distribution is presented in Table 7 for Sweden and the three foreign countries with most agreements, namely Germany, Poland and Estonia. The regional division corresponds to the 25 regional offices of the Swedish Construction Workers' Union that sign agreements with foreign companies operating temporarily in Sweden. For brevity's sake, only the five regions with most agreements are shown for each country. Agreements with German firms are concentrated in the southern parts of Sweden, while most Estonian agreements are to be found in Stockholm and neighbouring areas. Distance from the host country thus seems to be important; a short road distance in terms of kilometres or hours' driving is on the whole associated with more agreements in the region for each country. The economic size of the region (as reflected by the number of Swedish agreements) also seems to affect decisions to locate there. $^{18}$

\footnotetext{
${ }^{16}$ All foreign companies with posted workers do not sign agreements - Laval is a case in point - and it is probable that firms with very short spells in Sweden are underrepresented among firms with agreements. In addition, some agreements in the construction sector are signed by staffing agencies and these agreements may be difficult to assign to a specific industry.

${ }^{17}$ The region of the agreement refers to the region in which the firm was first active. Some firms may subsequently have extended their operations also to other regions, but these activities are not covered by the data.

${ }^{18}$ The findings regarding distance and economic size are in line with the predictions of the 'gravity model' of international trade (see, for example, Deardorff 1998).
} 
Table 6: Collective agreements between the Swedish Construction Workers' Union and construction firms, by country of origin, 2000-07

$20002001200220032004200520062007 \quad 2000-07$

\begin{tabular}{|c|c|c|c|c|c|c|c|c|c|}
\hline \multicolumn{10}{|l|}{ Nordic } \\
\hline $\begin{array}{l}\text { Countries } \\
\text { of which: }\end{array}$ & 9 & 9 & 13 & 26 & 24 & 27 & 29 & 13 & 150 \\
\hline Denmark & 2 & 2 & 3 & 10 & 5 & 7 & 5 & 0 & 34 \\
\hline Finland & 4 & 5 & 5 & 8 & 13 & 18 & 17 & 8 & 78 \\
\hline Norway & 3 & 2 & 5 & 8 & 6 & 2 & 7 & 5 & 38 \\
\hline \multicolumn{10}{|l|}{$\begin{array}{l}\text { Old EU } \\
\text { (excl. }\end{array}$} \\
\hline $\begin{array}{l}\text { Nordic) } \\
\text { of which }\end{array}$ & 2 & 8 & 9 & 52 & 45 & 39 & 47 & 64 & 266 \\
\hline Germany & 2 & 3 & 7 & 48 & 38 & 26 & 45 & 54 & 223 \\
\hline $\begin{array}{l}\text { New EU } \\
\text { of which: } \\
\text { Czech }\end{array}$ & 3 & 1 & 3 & 10 & 41 & 51 & 75 & 58 & 242 \\
\hline Republic & 0 & 0 & 0 & 0 & 2 & 1 & 1 & 2 & 6 \\
\hline Estonia & 0 & 0 & 1 & 5 & 3 & 11 & 14 & 9 & 43 \\
\hline Hungary & 3 & 1 & 0 & 0 & 1 & 4 & 3 & 4 & 16 \\
\hline Latvia & 0 & 0 & 1 & 1 & 3 & 3 & 3 & 5 & 16 \\
\hline Lithuania & 0 & 0 & 0 & 0 & 5 & 3 & 8 & 4 & 20 \\
\hline Poland & 0 & 0 & 1 & 2 & 25 & 28 & 40 & 28 & 124 \\
\hline Romania & 0 & 0 & 0 & 0 & 0 & 1 & 4 & 1 & 6 \\
\hline Slovakia & 0 & 0 & 0 & 2 & 2 & 0 & 2 & 5 & 11 \\
\hline $\begin{array}{l}\text { Non-EU } \\
\text { All foreign }\end{array}$ & 0 & 0 & 1 & 0 & 1 & 2 & 7 & 0 & 11 \\
\hline countries & 14 & 18 & 26 & 88 & 111 & 119 & 158 & 135 & 669 \\
\hline Sweden & 982 & 1191 & 1373 & 1585 & 1866 & 2263 & 2197 & 2194 & 13651 \\
\hline
\end{tabular}

Note: Figures for foreign countries refer to application agreements related to the Swedish Construction Agreement, applicable to firms that are not members of the Swedish Construction Federation and the Swedish Confederation of Enterprise, and (a small number of) agreements signed by firms with temporary membership. Figures for Sweden refer to regular and application agreements and include a small number of agreements signed by foreign-owned firms that are operating in Sweden on a permanent basis.

Source: Data by courtesy of Torbjörn Hagelin, Swedish Construction Workers’ Union.

\section{Wage effects}

Until recently, the domestic construction sector has largely been shielded from international competition. ${ }^{19}$ It is clearly possible that the increased competition since 2004, especially from low-wage countries, has decreased wage pressure in the industry as a whole. There is no systematic information about posted workers' wages, but they are likely to be lower than wages in Swedish firms, at least in firms from new member states. In general, worker skills and productivity levels in the latter firms are expected to be relatively low and they may also be more labour intensive than domestic firms. Although the inflow of foreign workers is not very large, the mere possibility of employers using their services may have contributed to wage restraint among Swedish workers.

\footnotetext{
${ }^{19}$ According to the Swedish Competition Authority (Konkurrensverket), the sector is characterised by the dominance of a few large companies, cartelisation among certain firms, slow technological development and widespread use of workers who do not declare their earnings (Swedish Competition Authority 2008).
} 
Table 7: Collective agreements between the Swedish Construction Workers' Union and construction firms from various countries, by top 5 Swedish regions, and road distance from capital of respective country to region, 2000-07

\begin{tabular}{|c|c|c|c|}
\hline & Agreements & $\begin{array}{l}\text { Road distance } \\
\text { from capital } \\
\mathrm{Km}\end{array}$ & Hours \\
\hline $\begin{array}{l}\text { Germany } \\
\text { all } 25 \text { regions } \\
\text { of which }\end{array}$ & 202 & & \\
\hline 1. Malmö & 73 & 471 & $6: 11$ \\
\hline 2. Halmstad & 32 & 607 & $7: 32$ \\
\hline 3. Väst & 19 & 817 & $10: 02$ \\
\hline 4. Helsingborg & 11 & 536 & $6: 50$ \\
\hline 5. Stockholm & 9 & 1075 & $12: 15$ \\
\hline $\begin{array}{l}\text { Poland } \\
\text { all } 25 \text { regions } \\
\text { of which }\end{array}$ & 117 & & \\
\hline 1. Stockholm & 24 & 1603 & 19:08 \\
\hline 2. Malmö & 21 & 1049 & $12: 51$ \\
\hline 3. Gothenburg & 16 & 1319 & $15: 30$ \\
\hline 4. Väst & 9 & 1395 & $16: 43$ \\
\hline 5. Värmland & 6 & 1581 & $19: 04$ \\
\hline $\begin{array}{l}\text { Estonia } \\
\text { all } 25 \text { regions } \\
\text { of which }\end{array}$ & 43 & & \\
\hline 1. Stockholm & 19 & 480 & $12: 07$ \\
\hline 2. Uppland & 6 & 483 & $12: 22$ \\
\hline 3. Borås & 2 & 886 & $16: 35$ \\
\hline 3. Luleå & 2 & 952 & $14: 13$ \\
\hline 3. Värmland & 2 & 770 & $15: 34$ \\
\hline 3. Väst & 2 & 877 & $17: 07$ \\
\hline $\begin{array}{l}\text { Sweden } \\
\text { all } 25 \text { regions } \\
\text { of which }\end{array}$ & 13651 & & \\
\hline 1. Stockholm & 2675 & & \\
\hline 2. Gothenburg & 1145 & & \\
\hline 3. Malmö & 961 & & \\
\hline 4. Helsingborg & 766 & & \\
\hline 5. Väst & 698 & & \\
\hline
\end{tabular}

Note: Road distance includes routes covered by passenger vessels. The total number of agreements for Germany, Poland and Estonia differs from the total in Table 6 since not all agreements could be assigned to a specific region. See also note to Table 6 .

Source: Swedish Construction Workers’ Union (agreements), Google Maps (road distance).

In order to examine the wage effects on Swedish workers in construction Table 8 presents GLS regressions for an extended 'wage curve' for 25 regions over the period 2001-07. Such a regression basically relates the real wage level to the unemployment rate, with a negative coefficient expected for the latter variable (see Blanchflower and Oswald 1995). The specification in the table adds the number of foreign agreements as explanatory variables (with the Swedish agreements as a control for size of region), the idea being that foreign agreements in relation to domestic ones serve as a proxy for the unobserved 'market penetration' of foreign firms in construction. All data are aggregated at the regional level and the wage and unemployment variables refer to union members in construction. The chosen wage measure is hourly piece-rates, which 
are negotiated for all new construction and thus should be more sensitive to fluctuations in demand and foreign competition than time-based pay. Some specifications add year and region dummies in order to control for macroeconomic and local conditions, respectively.

Table 8: Random-effects GLS (RE) and fixed-effects (FE) estimations, 2001-07 (dependent variable: Real log hourly wage for Swedish construction workers)

$\begin{array}{llll} & (1) & (2) & (3) \\ & \mathrm{RE} & \mathrm{RE} & \mathrm{FE} \\ \text { Log hourly } & & & \\ \text { wage, lagged } & \begin{array}{l}.9306^{* * *} \\ (.0279)\end{array} & \begin{array}{l}.8730^{* * *} \\ (.0434)\end{array} & .3934^{* * *} \\ & & & (.0992) \\ \text { Number of } & & & \\ \text { agreements: } & 0004 & -.0002 & .0003 \\ - \text { New EU } & (.0001) & (.0005) & (.0005) \\ \text { - Old EU and } & & & \\ \text { non-EU } & .0001 & (.0004) & .0006 \\ & (.0003) & .0000 & (.0004) \\ - \text { Sweden } & .0000 & (.0000) & -.0001 \\ & (.0000) & & (.0001) \\ \text { Log unemploy- } & & -.0039 & -.0176^{* *} \\ \text { ment rate } & -.0057 & (.0043) & (.0085) \\ & (.0036) & \text { Yes } & \text { Yes } \\ \text { Year dummies } & \text { No } & \text { No } & \text { Yes } \\ \text { Region dummies } & \text { No } & .897 & .790 \\ \text { Overall R2 } & .889 & \end{array}$

Note: There are 175 observations in all regressions. The constant is not reported. Robust standard errors (RE) within parentheses *** significance at 1 per cent level; ** 5 per cent; * 10 per cent.

Source: Own calculations, based on data from the Swedish Construction Workers' Union.

As expected, the unemployment rate (for members of the unemployment insurance fund in construction) comes out with a negative (and small) coefficient in Table 8, though only significantly so in the specification with both year and region dummies in column (3). More importantly, the number of agreements with companies from new (or old) EU member countries does not seem to matter for Swedish wages The strongest determinant is wages in the previous period, as indicated by the significant coefficient for the lagged dependent variable.

Using the number of agreements as a proxy for the inflow of foreign workers is a crude measure, as already pointed out, and mismeasurement of this variable should bias the effects of the agreements towards zero. Another potential problem with the regressions is reverse causation, which holds if the decision to locate in a specific region depends on the wage level. If a high wage level in a region attracts foreign firms, because it either reflects a high level of demand or signals a lack of competition that can be exploited, the effect from increased foreign competition on Swedish wages will be underestimated. With reverse causation and measurement errors, the true effect could be identified by using instruments that affect the foreign firms' decision to locate in the region, but not Swedish wages.

To this end, experiments were carried out with G2SLS IV estimations for two countries, Germany and Poland, with the road distance in hours (which worked better than kilometres) and a dummy for the post-enlargement period 2004-7 as instruments 26 
for the foreign agreements. The first-stage regressions show that distance has a negative effect on the number of agreements, while the dummy is positive and significant for Poland only (see Table 9). The size of the market (the number of Swedish agreements) also attracts firms from both countries. However, the IV estimations in Table 10 do not change the previous results that foreign agreements have had little effect on Swedish wages. ${ }^{20}$

Table 9: First-stage random-effects GLS (RE) regressions, 2001-07 (dependent variable: Number of collective agreements for German or Polish firms in the Swedish construction sector)

(1)

Germany

$\mathrm{RE}$

$$
-.2594^{* *}
$$

- Warsaw

Dummy for 2004-07

Log hourly wage, lagged

$$
-.5361
$$

Poland
RE

Number of agreements

$$
\text { - Sweden }
$$

Log unemployment rate

Yes

Year dummies

P-value (Wald)
(.4274)

$-2.5328$

$.0125^{* * *}$

Yes

.000

Note: All regressions include a constant. See also note to Table 8.

Source: Own calculations, based on data from the Swedish Construction Workers’ Union and Google Maps.

The results point to the conclusion that low-wage competition from new EU member states has not depressed Swedish wages in construction. This may be because the inflow of workers has been too small to have much of an effect or because the boom in the industry since 2004 has concealed the effect (in a way that is not captured by controlling for economy-wide conditions in the regressions). ${ }^{21}$ There is a caveat, however. The number of foreign workers could be too poorly measured and regional aggregation may hide effects in certain regions that would be possible to detect only with individual, and as of yet unavailable, wage data.

\footnotetext{
20 Unfortunately, it was not possible to find region-specific instruments that vary over time, so the regressions in Tables 8-9 do not allow for separate region-specific effects.

${ }^{21}$ A number of unreported robustness checks for the results in Table 8 were performed. These checks include GMM estimation, AR(1) estimation, inclusion of a trend, interacting the number of agreements with dummies for specific regions, deleting the lagged dependent variable and using time-based pay as the dependent variable. The results for the agreements remained basically unchanged.
} 
Table 10: Random-effects GLS (RE) and random-effects G2SLS IV regressions (REIV), 2001-07 (dependent variable: Real log hourly wage for Swedish construction workers)
(1)
(2)
(3)
(4)
RE
RE-IV
$\mathrm{RE}$
RE- IV

Number of

agreements

- Germany

$-.0001$

(.0004)

$-.0009$

- Poland

$-.0005--.0042$

$(.0011) \quad(.0054)$

Overall $\mathrm{R}^{2}$

.895

.897

.893

Note: All regressions include a constant, log hourly wage (lagged), number of agreements for Sweden, log unemployment rate and year dummies. The IV estimations also include road distances in hours to Berlin (regression 2) and Warsaw (regression 4) and a dummy for the period 2004-07 as instruments. See also note to Table 8.

Source: See Table 9.

\section{Conclusions}

Minimum wages in Sweden are negotiated in collective agreements and not regulated by law as is the case in most other countries. Nor are the rates legally extended to uncovered sectors as in Finland and Norway. The rates, which are differentiated by industry, are among the highest in the world in relation to average wages and have increased substantially since 1995 in most sectors. Minimum wages matter most in service sectors, such as retail and hotels/restaurants. The minimum wage policy in Sweden has contributed to the fact that few workers earn low wages and the virtual absence of the 'working poor' phenomenon. Minimum wages should also help explain why wage dispersion is relatively low compared to other countries. But success in these respects seems also to have come at a price in the form of lower employment among the young and the unskilled, although there is some uncertainty as regards the size of the disemployment effects.

The Laval case, which concerned construction workers posted by a Latvian company in Sweden, is the first of its kind in post-enlargement EU. The case poses specific challenges to the Swedish model of minimum wages. The European Court of Justice ruled that the minimum wages in construction were not clearly defined and some modification of the model will be necessary.

Up to now, the impact on the Swedish labour market of the inflow of posted workers has probably been limited. In construction, the increased inflow of foreign workers seems not to have affected Swedish wages negatively. To the extent that posted workers and domestic, underground workers who do not declare their earnings are substitutes in construction, the main brunt from increasing foreign competition may instead have been borne by the latter category, Nor do available data suggest that selfemployment has been used as a device to avoid minimum wage regulation to any large extent.

Nevertheless, the significance of the Laval case is likely to increase in the future, for a number of reasons. First, the inflow of posted workers may well spread to other industries previously shielded from international competition. There is great potential for low-wage competition from new EU members in services, since the wage share is much higher than in industries such as construction. The posted service workers may be employed by staffing agencies operating in Sweden. Second, it is not hard to think 
of a number of difficulties with regulating and monitoring minimum wages for posted workers from the new member states, regardless of how these rates are determined. Even if the foreign companies sign collective agreements, as many have done, it is difficult for the unions to get confirmation of the wage levels that the firms are obliged to report since there are no union members in the firms (Jacobsson, 2007). Should monitoring become more effective, increasing self-employment, a worker category for which no wage regulations apply, may be the response.

In the Swedish debate, it is frequently overlooked that creating 'equal minimum standards' is quite different from creating 'equal terms' in the sense that wages should be equal in foreign and Swedish firms. The latter notion is ill suited to a context where foreign firms with posted workers differ very much from Swedish firms in terms of worker skills, productivity and capital intensity. If anything, the Swedish experience with posted workers points to the importance of having clearly defined and allencompassing minimum wages - the model needs to be modified in this respect. The two main alternatives are a national minimum wage and legal extension to uncovered sectors.

A clear advantage with a legislated minimum wage is that it is indeed allencompassing, since the law would cover both foreign firms with posted workers and Swedish firms without collective agreements. It is difficult to envisage a sustainable solution to the difficulties associated with the Laval case without a regulatory framework that treats these two types of firms in the same way. A statutory minimum wage would probably entail lower rates than those in the collective agreements. This need not be a drawback, however, since much of the research points to disemployment effects of the currently prevailing, collectively agreed rates. A more serious question mark is perhaps related to the idea of political interference in wage formation, as there is a distinct risk of minimum wage levels becoming issues in national election campaigns for short-run political gains. By creating an independent government body, like the Low Pay Commission in the United Kingdom, with representatives of unions, employers and researchers, a more long-term perspective to minimum wage issues could be achieved.

Extension of collective agreements to uncovered sectors could also potentially create a level playing field, in terms of minimum standards, for foreign firms with posted workers and Swedish firms, with or without collective agreements. But the sustainability of this approach is questionable. Should union membership continue to decline, a situation may arise where the legislator cannot consider the collective agreements to be representative enough for the industries concerned. Although not an immediate concern in Sweden, this seems already to be looming in the future for Finland, where extensions have been used widely and union membership in some industries is nearing the critical 50 per cent mark (Böckerman and Uusitalo 2006). Unionisation rates also tend to be lower in services, where the role of minimum wages for pushing up the lowest wages is relatively more important. In addition, the possibilities for workers to free-ride on union benefits through legal extensions of collective agreements to uncovered sectors create disincentives for union membership, which could reduce membership even further.

As should be evident from this report, striking a balance between safeguarding domestic wage levels and reaping the benefits from the possibilities for companies to offer their services across the whole EU will not be an easy task. 


\section{References}

Abowd, J.M., F. Kramarz, T. Lemieux and D.N. Margolis (2000a) 'Minimum Wages and Youth Employment in France and the United States', in D. Blanchflower and R. Freeman (eds), Youth Employment and Joblessness in Advanced Countries, University of Chicago Press.

Abowd, J.M., F. Kramarz, D.N. Margolis and T. Philippon (2000b) 'The Tail of Two Countries: Minimum Wages and Employment in France and the United States’, IZA DP No. 203.

Albæk, K., and E. Strøjer Madsen (1987) 'Wage Distributions and Employment Effects of the Danish Minimum Wage', in R. Lund, P.J. Pedersen and J. Beyer Schmidt-Sorensen (eds), Studies in Unemployment, New Social Science Monographs, Copenhagen.

Askildsen, J.E., K.E. Lommerud, Ø.A. Nilsen and K.G. Salvanes (2000) 'Union Bargained Minimum Wages: Are There Any Employment Effects?’, mimeo, University of Bergen, Norway.

Bazen, S. (2000) 'The Impact of the Regulation of Low Wages on Inequality and Labour-Market Adjustment: A Comparative Analysis', Oxford Review of Economic Policy, 16: 57-69.

Blanchflower, D.G., and A.J. Oswald (1995) The Wage Curve, Cambridge, MA: MIT Press,.

Böckerman, P. and R. Uusitalo (2006) 'Erosion of the Ghent System and Union Membership Decline: Lessons from Finland’, British Journal of Industrial Relations, 44: 283-303.

Böckerman, P., and R. Uusitalo (2007) 'Minimum Wages and Youth Employment: Evidence from the Finnish Retail Trade Sector', Discussion Paper 238, Labour Institute for Economic Research, Helsinki.

Deardorff, A.V. (1998) 'Determinants of Bilateral Trade: Does Gravity Work in a Neoclassical World?', in J.A. Frankel (ed.), The Regionalization of the World Economy, University of Chicago Press.

Dolado, J.J., F. Felgueroso and J.F. Jimeno (2000) 'The Role of the Minimum Wage in the Welfare State: An Appraisal', Swiss Journal of Economics and Statistics, 136: 223-45.

Dølvik, J.E., and L. Eldring (2008) Arbeidsmobilitet fra de nye EU-landene til Norden utviklingstrekk og konsekvenser, TemaNord 2008:502, Nordic Council of Ministers, Copenhagen.

Edin, P.-A., and B. Holmlund (1994) Arbetslösheten och arbetsmarknadens funktionssätt, appendix 8 to Långtidsutredningen 1994. Stockholm: Fritzes.

Edin, P.-A., and B. Holmlund (1995) 'The Swedish Wage Structure: The Rise and Fall of Solidaristic Wage Policy?’, in R. Freeman and L. Katz (eds), Differences and Changes in Wage Structures', University of Chicago Press.

Edin, P.-A., and R. Topel (1997) 'Wage Policy and Restructuring: The Swedish Labor Market since 1960', in R. Freeman, B. Swedenborg and R. Topel (eds), The Welfare State in Transition - Reforming the Swedish Model, University of Chicago Press.

EIRO (2005) 'EIRO Internet-Artikel, 3. Quartal 2005', European Industrial Relations Observatory.

Eklund, A.-K. (2008) 'Sjuksköterskornas löner måste upp 1700 kronor', Dagens Nyheter (2 February).

Fahlbeck, R. (2006) 'Svenska sympatiåtgärder i ett internationellt perspektiv', Ratio, Stockholm.

Gustafsson, B., A. Zaidi and E. Franzén (2007) 'Financial Poverty', International Journal of Social Welfare, 16: S67-S90.

Jacobsson, G. (2007) 'Handslaget gjorde ingen större skillnad', LO-tidningen (12 October).

Jacobsson, G. (2008) 'Handeln tvekar om minimilöner’, LO-tidningen (29 January).

Katz, L., and D. Autor (1999) 'Changes in the Wage Structure and Earnings Inequality', in O. Ashenfelter and D. Card (eds), Handbook of Labor Economics, Vol. 3A, Amsterdam: North Holland.

Kjellberg, A. (2003) 'Arbetsgivarorganisationer och fackföreningar i ett föränderligt arbetsliv', in C. von Otter (ed.), Ute och inne i svenskt arbetsliv, Stockholm: National Institute for Working Life.

Kramarz, F., and T. Philippon (2001) 'The Impact of Differential Payroll Tax Subsidies on Minimum Wage Employment', Journal of Public Economics, 82: 115-46.

Lindström, A. (2008) '2007 års avtalsrörelse', in A. Thoursie (ed.), Vems ordning och reda? Framtidens kollektivavtal och fackliga samarbete. Agoras årsbok 2007, Stockholm: Tankesmedjan Agora.

Low Pay Commission (2005) National Minimum Wage. Low Pay Commission Report 2005, London. 
Lundby-Wedin, W., and E. Olausson (2008) 'Lavaldomen kan tvinga LO att ändra lönepolitik’, Dagens Nyheter (8 January).

National Institute for Economic Research (2007) Lönebildningsrapporten 2007, Stockholm: National Institute for Economic Research.

National Mediation Office (2006) Avtalsrörelsen och lönebildningen 2005. Medlingsinstitutets årsrapport, Stockholm: National Mediation Office.

National Mediation Office (2007) Avtalsrörelsen och lönebildningen 2006. Medlingsinstitutets årsrapport, Stockholm: National Mediation Office.

National Mediation Office (2008) Avtalsrörelsen och lönebildningen 2007. Medlingsinstitutets årsrapport, Stockholm: National Mediation Office.

Neumark, D., and W. Wascher (2004) 'Minimum Wages, Labor Market Institutions, and Youth Employment: A Cross-National Analysis', Industrial and Labor Relations Review, 57: 223-48.

Neumark, D., and W. Wascher (2007) Minimum Wages and Employment, Foundations and Trends in Microeconomics 3: 1-2, Hanover, MA: Now Publishers.

Niklasson, C., and K. Connheim (2008) 'Krångel hejdar medlemsvärvning. Byggnads inte anpassat för utländska arbetare', Byggnadsarbetaren, No. 3 (February).

Nordström Skans, O., P.-A. Edin and B. Holmlund (2006) 'Wage Dispersion between and within Plants’, Working Paper 2006:9, Uppsala: Institute for Labour Market Policy Evaluation.

Östros, T. (1994) 'Do Minimum Wages Matter? The Case of Swedish Mining and Manufacturing', in B. Holmlund (ed.), Pay, Productivity, and Policy. Essays on Wage Behavior in Sweden, Stockholm: Trade Union Institute for Economic Research (FIEF).

Skedinger, P. (2005) 'Hur höga är minimilönerna?', Rapport 2005:18, Uppsala: Institute for Labour Market Policy Evaluation.

Skedinger, P. (2006) 'Minimum Wages and Employment in Swedish Hotels and Restaurants', Labour Economics, 13: 259-90.

Swedish Association of Local Authorities and Regions (2005) 'Rätt uppgifter om lönevillkor', Stockholm: Swedish Association of Local Authorities and Regions.

Swedish Association of Local Authorities and Regions (2008) 'Strejken över - treårigt avtal klart', press release, 28 May 2008, Swedish Association of Local Authorities and Regions, http://www.skl.se/artikel.asp?A=53246andC=406, accessed 22 June 2008.

Swedish Competition Authority (2008) Konkurrensen i Sverige 2007, Stockholm: Swedish Competition Authority.

Weihe, A (2008) ‘Ändrad lagstiftning nödvändigt efter Laval-domen’, Association of Swedish Engineering Industries, http://www.teknikforetagen.se/templates/News__2987.aspx, accessed 23 June 2008. 